\title{
Estrogen-like Activity of Tamoxifen and Raloxifene on NMDA Receptor Binding and Expression of its Subunits in Rat Brain
}

\author{
Michel Cyr, Ph.D., Caroline Thibault, B.Sc., Marc Morissette, Ph.D., \\ Michelle Landry, M.Sc., and Thérèse Di Paolo, Ph.D.
}

\begin{abstract}
Hormonal specificity of modulation of $\mathrm{N}$-methyl$D$-aspartate (NMDA) receptors was investigated by comparing the effects of estradiol with tamoxifen or raloxifene, which display different responses in breast, bone, and uterus. Two weeks ovariectomy in rats decreased uterine weight, which was prevented by a two-week estradiol treatment; tamoxifen and raloxifene had weaker uterine stimulation than estradiol. Ovariectomy in rats decreased $L-\left[{ }^{3} \mathrm{H}\right]$ glutamate specific binding to NMDA receptors in $C A 1$ and dentate gyrus but not $C A 2 / 3$ regions of hippocampus and was without effect in cortex, striatum, nucleus accumbens, and olfactory tubercle. [ $\left.{ }^{3} \mathrm{H}\right]$ Ro 25-6981 (an NMDA antagonist selective for NR1/NR2B assembly) specific binding and $m R N A$ levels of NMDA receptor subunits 1 and $2 B$ decreased in CA1 after ovariectomy. Estradiol, tamoxifen, and raloxifene decreased $L-\left[{ }^{3} \mathrm{H}\right]$ glutamate specific binding to NMDA receptors and
\end{abstract}

KEY WORDS: Ovariectomy; Raloxifene; Tamoxifen; Estradiol; N-methyl-D-aspartate receptor; Glutamate

From the Oncology and Molecular Endocrinology Research Center, Laval University Medical Center, (CHUL), and Faculty of Pharmacy, Laval University, Sainte-Foy, Quebec, Canada, G1V 4G2.

Address correspondence to: Dr. Thérèse Di Paolo, Oncology and Molecular Endocrinology Research Center, Laval University Medical Center, CHUQ, 2705, Laurier Boulevard, Sainte-Foy, Quebec, Canada G1V 4G2.

Received July 5, 2000; revised December 20, 2000; accepted January 3, 2001. $\left[{ }^{3} \mathrm{H}\right]$ Ro 25-6981 specific binding in cortical area of ovariectomized rats and prevented the decrease of $\left[{ }^{3} \mathrm{H}\right]$ glutamate specific binding to NMDA receptors in CA1 and dentate gyrus, as well as $\left[{ }^{3} \mathrm{H}\right]$ Ro 25-6981 specific binding in CA1. Estradiol prevented the decrease of NMDA receptor subunits 1 and $2 B m R N A$ levels in $C A 1$ only; tamoxifen and raloxifene prevented the decrease of NMDA receptor subunit $1 \mathrm{mRNA}$ levels in CA1. No effect of ovariectomy or treatments on L- $\left[{ }^{3} H\right] C G P 39653$ (an NMDA antagonist selective for NR1/NR2A assembly) specific binding and NMDA receptor subunit $2 A$ mRNA levels was observed in all brain regions assayed. Our results showed brain regional and subunits specific agonist estrogenic activity of tamoxifen and raloxifene on NMDA receptors.

[Neuropsychopharmacology 25:242-257, 2001] (C) 2001 American College of Neuropsychopharmacology. Published by Elsevier Science Inc.

It has been shown that the female sex steroid estradiol exerts profound effects on neuronal differentiation during development (Toran-Allerand et al. 1983) and recently, accumulating evidence support also a modulatory role of estrogens in the normal maintenance of brain function during aging (Simpkins et al. 1994). Beneficial effects of estradiol in mood disorders (i.e., depression, pre-menstrual syndrome, post-natal depression), as well as mental diseases, such as schizophrenia and Gille de la Tourette's syndrome, have been reported (Di Paolo 1994; Fink et al. 1998). Moreover, a beneficial role of estradiol in neurodegenerative dis- 
eases, such as Alzheimer has been recently suggested (Tang et al. 1996; Henderson 1997; Inestrosa et al. 1998). However, the mechanisms by which these effects of estrogens are yet to be fully characterized.

$\mathrm{N}$-methyl-D-aspartate (NMDA) receptors, a subtype of ionotropic glutamate receptor, have been implicated, as mediators, in some effects of estradiol on morphological plasticity and related physiological and cognitive processes in the brain (Moriyoshi et al. 1991). However, only few studies have directly investigated the role of estradiol in regulating NMDA receptors in rat and, in addition, these studies have focused on the effects of estradiol on hippocampal NMDA receptors (Woolley and McEwen 1992; Gazzaley et al. 1996; Woolley et al. 1997). We have recently investigated the effects of estradiol on the NMDA receptors agonist sites in brain regions implicated in mental disorders, such as frontal cortex, striatum, and nucleus accumbens (Cyr et al. 2000a). Our experiments showed that ovariectomy, as well as estradiol have regional specific effects since, for example, ovariectomy decreases NMDA receptor specific binding in hippocampal CA1 and dentate gyrus regions, whereas it has no effect in frontal cortex. In contrast, estradiol increases NMDA specific binding in the hippocampal CA1 and the dentate gyrus, but it decreases this binding in the frontal cortex (Cyr et al. 2000a).

The present study sought to determine whether changes observed previously at the protein level after hormonal withdrawal due to ovariectomy or after estradiol treatment reflect changes at the level of gene transcription, as well as to determine which subunits of the NMDA receptor may be implicated in this hormonal modulation. Therefore, we have investigated by autoradiography the levels of NMDA receptors agonist sites using L- $\left[{ }^{3} \mathrm{H}\right]$ glutamate and of NMDA receptors competitive antagonist sites using L- $\left.{ }^{3} \mathrm{H}\right]$ CGP 39653 and $\left[{ }^{3} \mathrm{H}\right]$ Ro 25-6981 two weeks after ovariectomy and chronic administration of estradiol in rats. We have also investigated by in situ hybridization, using specific oligonucleotides, the level of NMDA receptor subunits 1 , $2 \mathrm{~A}$, and $2 \mathrm{~B}$ mRNA. The regions of the brain chosen were those implicated in mental disorders such as cingulate, frontal, and parietal cortices, striatum, nucleus accumbens, and hippocampus.

Activity in the rat brain of estrogen receptor ligands which have shown tissue-specific estrogen agonist and/or antagonist effects in peripheral tissues has not been reported on NMDA receptor binding or expression. Tamoxifen, a mixed estrogen agonist-antagonist used in the prevention and treatment of breast cancer, is among the first generation of the selective estrogen receptor modulators considering that it acts as an estrogen antagonist in mammary tissue, whereas it mimics the effects of estrogen in other tissues (Sato et al. 1996). Raloxifene, is among the second generation of selec- tive estrogen receptor modulators and it acts as an estrogen antagonist in mammary and uterine tissues, whereas functions as an estrogen agonist in bone and cholesterol metabolism (Sato et al. 1996). Raloxifene is used to treat osteoporosis (Levenson and Jordan 1999). Hence, these two molecules act as estrogen agonist or antagonist depending on the peripheral tissue. Therefore, we sought brain effects on the NMDA receptors of selective estrogen receptor modulators separate from their uterine stimulation by analogy to their skeletal/ cardiovascular activity. We hypothesize that estrogen agonist or selective estrogen receptor modulators change neuronal activity by affecting various neurotransmitters in different brain areas, which can bring a novel equilibrium in the brain. The present study investigated the specificity of estradiol and estrogen-receptor directed drugs modulation of the NMDA receptors. This knowledge is potentially important for a better understanding of estrogen receptors and glutamate receptors interaction.

\section{MATERIAL AND METHODS}

\section{Animals}

Adults female Sprague-Dawley rats weighing approximately $250 \pm 10 \mathrm{~g}$ were purchased from Charles River Canada Inc., St-Constant, Quebec, Canada. They were housed two per cage and maintained at $22-23^{\circ} \mathrm{C}$ for two weeks on a $12 \mathrm{h:} 12 \mathrm{~h}$ light/dark cycle (lights on from 0700 to 1900). The rats received rat chow and water ad libitum. The protocols used in these experiments were all approved by the Laval University Animal Care Committee and all efforts were made to minimize animal suffering and to reduce the number of rats used.

\section{Treatments}

The experiment included age-matched adult rats randomly divided into six groups of nine animals each. The first group included non-ovariectomized intact control rats at random stages of the estrous cycle treated with vehicle and the remaining five groups consisted of two-weeks ovariectomized rats under anesthesia (1.5\% halothane air mixture) treated with vehicle, 80 $\mu \mathrm{g} / \mathrm{kg}$ 17ß-estradiol (SIGMA, St. Louis, MO), $1 \mathrm{mg} / \mathrm{kg}$ tamoxifen citrate (SIGMA), or $1 \mathrm{mg} / \mathrm{kg}$ raloxifene (gift of F. Labrie, Oncology and Molecular Endocrinology Research Center, Quebec, Canada). Raloxifene was synthesized in the laboratory of Dr F. Labrie; purity $(99.10 \%)$ and identity were assessed by High Pressure Liquid Chromatography, ${ }^{1} \mathrm{H}$ and ${ }^{13} \mathrm{C}$ NMR and Fourier Transform Infrared Spectroscopy.

An other group of ovariectomized rats received an experimental drug and the results are not presented. The drug doses were chosen for maximal occupancy of 
the estrogen receptors and the vehicle was chosen for maximal delivery (Martel et al. 1998). Similar drug doses and vehicle were previously used to investigate the effects of estradiol, tamoxifen, and raloxifene on brain $5-\mathrm{HT}_{2 \mathrm{~A}}$ receptors (Cyr et al. 2000b). Treatment began the day after ovariectomy once daily for 14 days; $0.5 \mathrm{ml} /$ rat was injected subcutaneously as suspension, the vehicle consisting of $4 \%$ ethanol, $4 \%$ polyethylene glycol 600 (PEG600 ), $1 \%$ gelatin, and $0.9 \% \mathrm{NaCl}$ in water. The uterus of the rats were immediately removed after sacrifice, freed from connective and adipose tissue, and weighed.

\section{Brain Sections Preparation}

The animals were killed in the morning by decapitation and their brains were rapidly removed, quickly frozen in isopentane over dry ice, individually wrapped in aluminum foil, and kept at $-80^{\circ} \mathrm{C}$. Brains were immersed in Tissue-Tek (Miles Inc., Elkhart, USA) at $-20^{\circ} \mathrm{C}$, mounted on cryostat chucks, and cut into $20 \mu \mathrm{m}$ thick coronal sections. Adjacent coronal sections were from the prefrontal cortex to the striatal regions of the brain (Bregma 4.2 to $1.2 \mathrm{~mm}, n=80$ sections) and from the hippocampal regions (Bregma -3.0 to $-4.4 \mathrm{~mm}, n=$ 40 sections) according to the atlas of Paxinos and Watson (1982).

The effect of hormonal modulation was studied in these brain regions, which were chosen based upon their importance in mental diseases, such as schizophrenia and depression, their high density of NMDA receptor and their mRNA expression, and/or the presence of estrogen receptors. Sections were thawmounted on superfrost pre-cleaned slides (Trade Mark, Fisher, Nepean, Ontario, Canada) and were then vacuum-desiccated at $4^{\circ} \mathrm{C}$ for 12 hours before storing them at $-80^{\circ} \mathrm{C}$.

\section{L- $\left[{ }^{3} \mathrm{H}\right]$ glutamate Binding Autoradiography}

Autoradiography of glutamate and NMDA receptor agonist sites using L- $\left[{ }^{3} \mathrm{H}\right]$ glutamate was performed as previously described (Cyr et al. 2000a). Slide-mounted brains sections were preincubated for $10 \mathrm{~min}$ at $30^{\circ} \mathrm{C}$ in the incubation buffer: $50 \mathrm{mM}$ Tris-Acetate, $\mathrm{pH}$ 7.2. Slides were dried briefly and then incubated with 100 nM L- $\left[{ }^{3} \mathrm{H}\right.$ ]glutamate [49.4 Ci/mmol; New England Nuclear (NEN)] for $45 \mathrm{~min}$ at $4^{\circ} \mathrm{C}$.

To determine nonspecific binding, $0.2 \mathrm{mM}$ of L-glutamic acid hydrochloride (Research Biochemical Inc. (RBI) Natik, USA) was added to the incubation buffer; to determine the specific binding of NMDA receptors, $100 \mu \mathrm{M}$ of NMDA acid (RBI) was added to the incubation buffer. Therefore, the specific binding of NMDA receptors was defined as the amount of L- $\left[{ }^{3} \mathrm{H}\right]$ glutamate binding that was displaced by NMDA. After incubation, the slides were placed in racks and washed three times for 8 sec each in incubation buffer at $4^{\circ} \mathrm{C}$, fixed in acetone with $2.5 \%$ glutaraldehyde, and dried under a fan. Sections were apposed to Amersham Hyperfilm ${ }^{3} \mathrm{H}$ with calibrated standards (Microscale, Amersham) and exposed for 14 days. Autoradiograms were analyzed using the software package NIH Image 1.68 on a Power Macintosh 7100 assisted videodensitometry (Sony camera XC-77), which provide values of receptors densities expressed in $\mathrm{fmol} / \mathrm{mg}$ of tissue.

Optical density measurements were performed on the total area of the cingulate, frontal, and parietal cortices, the dorsal and ventral part of the striatum, the nucleus accumbens, and the olfactory tubercle (Bregma $1.60 \mathrm{~mm}$ ) (Paxinos and Watson 1982), as well as on the total area of hippocampal CA1 and CA2/3 subfields (including oriens, pyramidal cell, and stratum radiatum layers) and molecular layer dentate gyrus (Bregma $-3.80 \mathrm{~mm}$ ) (Paxinos and Watson 1982). Values for each group were the mean of six animals.

For each animal brain structure, specific binding of $\mathrm{L}-\left[{ }^{3} \mathrm{H}\right]$ glutamate was estimated by subtracting nonspecific binding (in the presence of L- $\left[{ }^{3} \mathrm{H}\right]$ glutamate and $0.2 \mathrm{mM}$ L-glutamic acid hydrochloride) from eight adjacent coronal sections to the total L- $\left[{ }^{3} \mathrm{H}\right]$ glutamate binding from eight other adjacent coronal sections, whereas specific binding of NMDA was estimated by subtracting the L- $\left[{ }^{3} \mathrm{H}\right]$ glutamate/NMDA binding from eight adjacent coronal sections to the total L- $\left[{ }^{3} \mathrm{H}\right]$ glutamate binding. Examples are shown in Figures 1 and 2.

\section{L- $\left[{ }^{3} \mathrm{H}\right]$ CGP 39653 and $\left[{ }^{3} \mathrm{H}\right]$ Ro 25-6981 Binding Autoradiography}

The L-[ $\left.{ }^{3} \mathrm{H}\right]$ CGP 39653 (40 Ci/mmol, NEN) binding autoradiography was adapted from Jaarsma et al. (1993). Briefly, the slides were preincubated three times for 20 minutes in Tris- $\mathrm{HCl}$ buffer $(50 \mathrm{mM}, \mathrm{pH} 8.0)$ at room temperature. Sections were then incubated with $20 \mathrm{nM}$ of L- $\left[{ }^{3} \mathrm{H}\right]$ CGP 39653 for $90 \mathrm{~min}$ at $4^{\circ} \mathrm{C}$ in $50 \mathrm{mM}$ Tris$\mathrm{HCl}$ buffer ( $\mathrm{pH}$ 8.0) containing 30 units $/ \mathrm{ml}$ of glutamate dehydrogenase (Boehringer Mannheim, Indianapolis, IN, USA), $1.1 \mathrm{mM}$ nicotinamide-adenine dinucleotide (SIGMA), and $0.03 \%$ hydrazide (v/v; SIGMA). Sections were then rinsed three times for 20 sec at $4^{\circ} \mathrm{C}$ in Tris- $\mathrm{HCl}$ buffer ( $50 \mathrm{mM}, \mathrm{pH}$ 8.0). Nonspecific binding was determined by adding $0.5 \mathrm{mM}$ L-NMDA (SIGMA) to the incubation buffer and the binding was always less than $5 \%$.

$\left[{ }^{3} \mathrm{H}\right]$ Ro 25-6981 (26 Ci/mmol; gift from F. HoffmanLa Roche Ltd., Basel, Switzerland) is an ifenprodil derivative (Fischer et al. 1997; Mutel et al. 1998) but in contrast to $\left[{ }^{3} \mathrm{H}\right]$ Ifenprodil, $\left[{ }^{3} \mathrm{H}\right]$ Ro $25-6981$ binding does not appear to be very sensitive to $\sigma$ ligands and has a low relative affinity to $\alpha_{1}$-adrenergic, as well as serotoninergic binding sites (Mutel et al. 1998). $\left[{ }^{3} \mathrm{H}\right]$ Ro 25-6981 binding autoradiography was adapted from Mutel et 


\section{$\mathrm{L}-[3 \mathrm{H}]$ Glutamate binding}

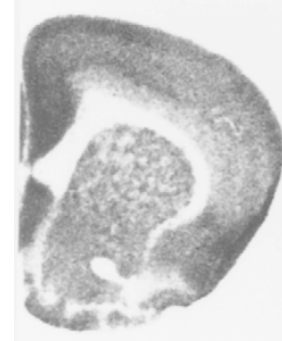

Vehicle

Intact

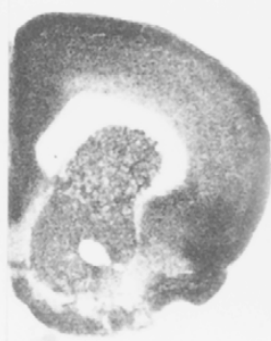

Vehicle

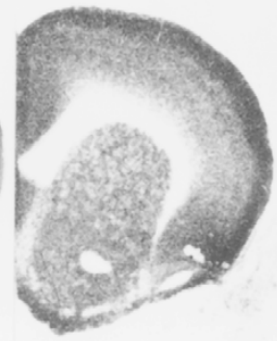

Estradiol

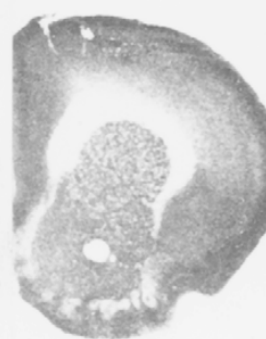

Tamoxifen

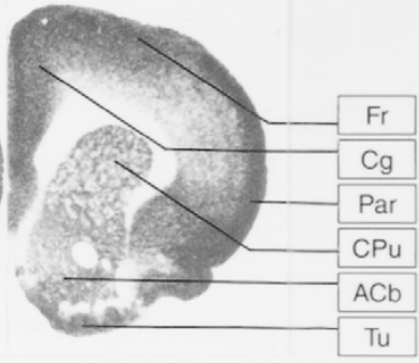

Raloxifene

Figure 1. Autoradiograms of coronal rat brain sections showing binding of L- $\left[{ }^{3} \mathrm{H}\right]$ Glutamate $(0.2 \mathrm{mM})$ to glutamate receptors in the cortical regions, striatum, nucleus accumbens, and olfactory tubercle (Bregma 2.20) (Paxinos and Watson 1982) of intact rats and ovariectomized rats (two weeks) that received vehicle once daily, s.c., or a replacement therapy for two weeks with $17 \beta$-estradiol $(80 \mu \mathrm{g} / \mathrm{kg})$, tamoxifen $(1 \mathrm{mg} / \mathrm{kg})$, or raloxifene (1mg/kg). Abbreviations: Acb, nucleus accumbens; Cg, cingulate cortex; $\mathrm{CPu}$, caudate putamen (striatum); Fr, frontal cortex; Par, parietal cortex; $\mathrm{Tu}$, olfactory tubercle.

\section{NMDA receptor}

\section{Binding autoradiography}

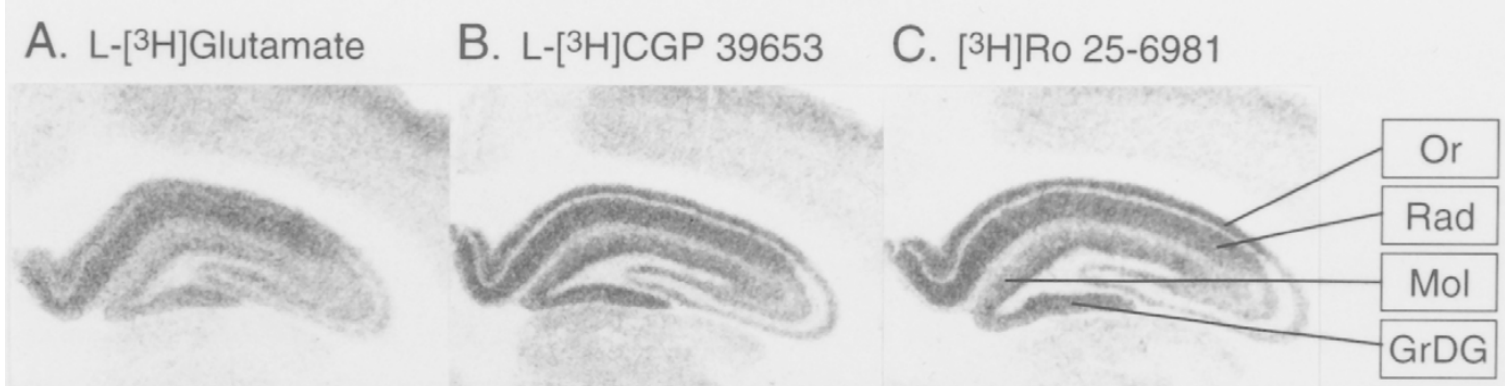

\section{In situ hybridization}

D. subunit 1

E. subunit $2 A$

F. subunit $2 B$

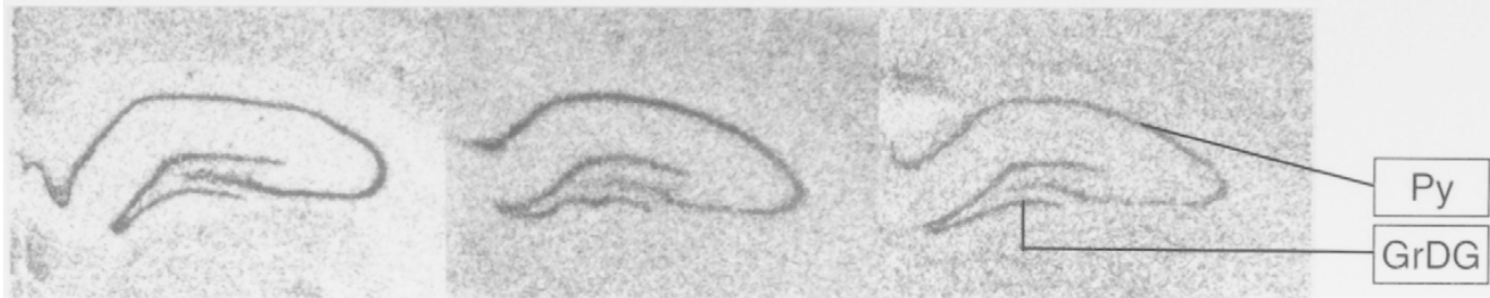

Figure 2. Examples of binding autoradiography using $(\mathbf{A}) \mathrm{L}-\left[{ }^{3} \mathrm{H}\right] \mathrm{Glutamate}(0.2 \mathrm{mM})$ binding to glutamate receptors, $(\mathbf{B})$ L- $\left[{ }^{3} \mathrm{H}\right]$ CGP $39653(20 \mathrm{nM})$ binding to NMDA receptors subunits 1/2A, and (C) [ $\left.{ }^{3} \mathrm{H}\right]$ Ro $25-6981$ (5 nM) binding to NMDA receptors subunits $1 / 2 \mathrm{~B}$. Shown are also examples of in situ hybridization using specific [ ${ }^{35} \mathrm{~S}$ ] oligonucleotides directed against the NMDA receptor (D) subunit 1, (E), subunit 2A, and (F) subunit 2B in hippocampal regions (Bregma -3.80 to $-4.20 \mathrm{~mm}$ ) (Paxinos and Watson 1982) of intact rat. Abbreviations: GrDG, granular layer dentate gyrus; Mol, molecular layer dentate gyrus; Or, oriens layer; Py, pyramidal cell layer; Rad, stratum radiatum. 
al. (1998). Briefly, the slides were preincubated two times for $10 \mathrm{~min}$ in incubation buffer (Tris- $\mathrm{HCl} 50 \mathrm{mM}$, EDTA $10 \mathrm{mM}, \mathrm{pH}$ 7.6) at room temperature. Sections were then incubated with $5 \mathrm{nM}$ of $\left[{ }^{3} \mathrm{H}\right] \mathrm{Ro} 25-6981$ for 90 $\min$ at $4^{\circ} \mathrm{C}$ in incubation buffer. Sections were then rinsed three times $(2 \times 5 \mathrm{~min}$ and $1 \times 15 \mathrm{~min})$ at $4^{\circ} \mathrm{C}$ in incubation buffer. Nonspecific binding was determined by adding $10 \mu \mathrm{M}$ Ro 04-5595 hydrochloride (gift from F. Hoffman-La Roche Ltd.) to the incubation buffer and was almost undetectable on film autoradiograms.

Sections from both L- $\left[{ }^{3} \mathrm{H}\right] \mathrm{CGP} 39653$ or $\left[{ }^{3} \mathrm{H}\right]$ Ro $25-$ 6981 binding autoradiography were apposed to Amersham Hyperfilm ${ }^{3} \mathrm{H}$ with calibrated standards (Microscale, Amersham, UK) for two weeks and autoradiograms were analyzed using the software package NIH Image 1.68 on a Power Macintosh 7100 assisted videodensitometry (Sony camera XC-77, $65 \mathrm{~mm}$ ) to obtain values of receptor densities expressed in $\mathrm{fmol} / \mathrm{mg}$ of tissue. The lens of the Sony camera XC-77 was of $65 \mathrm{~mm}$ instead of $35 \mathrm{~mm}$ as for L- $\left[{ }^{3} \mathrm{H}\right]$ glutamate binding autoradiography, for better anatomical resolution of the hippocampal regions. Values for each group were the mean of nine animals and the mean for each animal was obtained from the measurements of the total area of eight adjacent sections of cingulate cortex (Bregma $2.80 \mathrm{~mm}$ ) (Paxinos and Watson 1982); note that these sections are anterior to those used in L- $\left[{ }^{3} \mathrm{H}\right]$ glutamate binding experiments. The total area of eight adjacent sections of the oriens layer and the stratum radiatum of hippocampal CA1 and CA2/3 subfields as well as the molecular layer dentate gyrus was measured (Bregma $-4.00 \mathrm{~mm}$ ) (Paxinos and Watson 1982). Examples are shown in Figures 2, 5, and 10.

\section{In Situ Hybridization of NMDA Receptors}

In situ hybridization was performed using previously published sequences of oligonucleotides (Monyer et al. 1992) complementary to rat cRNA encoding subunits residues between transmembrane domains I and II, encoding amino acids $566-580$ of the mature peptide NMDA receptors subunit 1 (5'-TTCCTCCTCCTCCTCACTGTTCACCTTGAATCGGCCAAAGGGACT-3'), 567-579 of the NMDA receptors subunit 2A (5'-AGAAGGCCCGTGGGGAGCTTTCCCTTTGGCTAAGTTTC-3'), and 557-572 of the NMDA receptors subunit 2B (5'-GGGCCTCCTGGCTCTCTGCCATCGGCTAGGCACCTGTTGTAACCC-3'); note that the sequence of the oligonucleotide against NMDA receptor subunit 1 mRNA detects a population of eight distinct isoforms of a number of alternative splice variants (Sugihara et al. 1992; Hollmann et al. 1993).

\section{Cortical region}

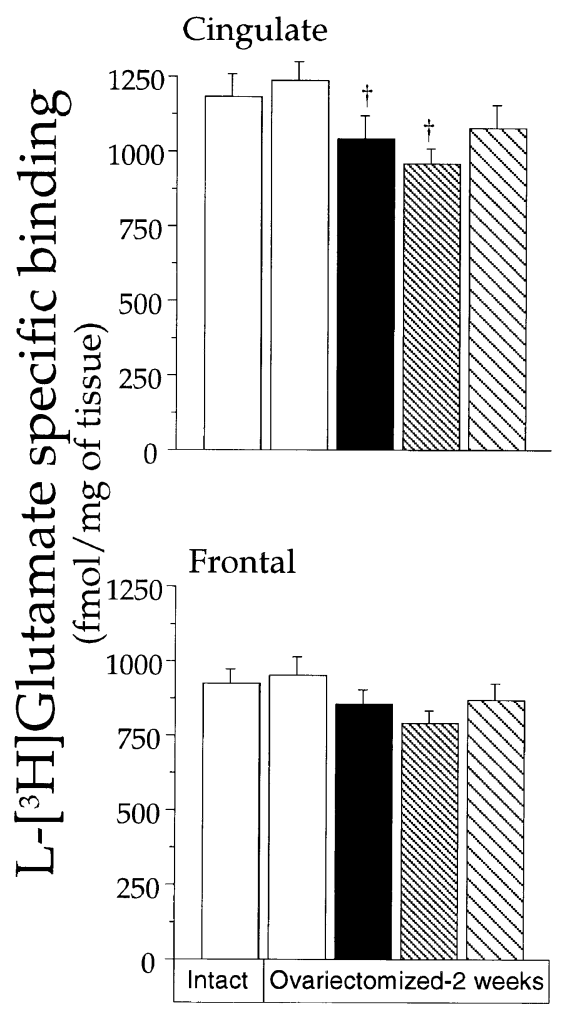

Hippocampal region
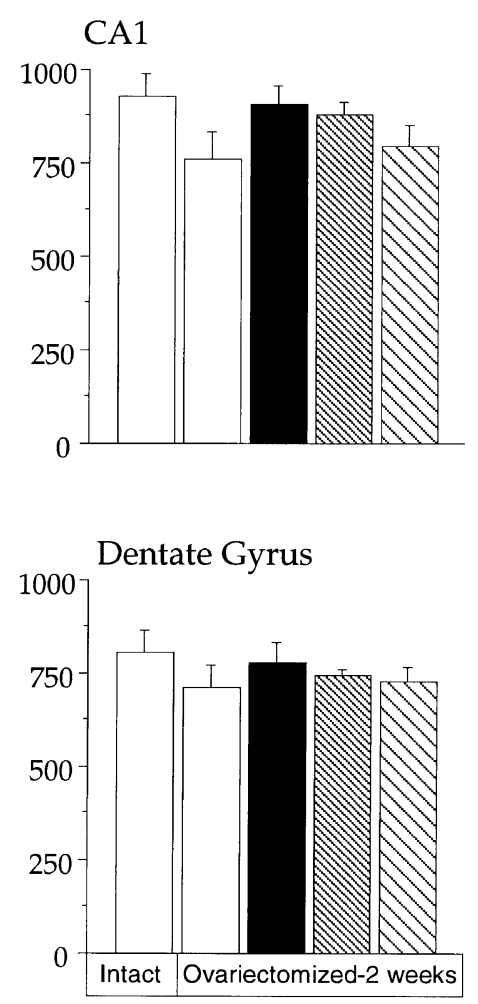

$\square$ Vehicle Tamoxifen

Figure 3. L- $\left[{ }^{3} \mathrm{H}\right]$ Glutamate $(0.2 \mathrm{mM})$ specific binding to glutamate receptors and transporters in the cortical and hippocampal regions of intact rats and two-weeks ovariectomized rats that received vehicle once daily, s.c., or a two-week replacement therapy with $17 \beta$-estradiol $(80 \mu \mathrm{g} / \mathrm{kg}$ ), tamoxifen $(1 \mathrm{mg} / \mathrm{kg})$, or raloxifene $(1 \mathrm{mg} /$ $\mathrm{kg}$ ). No effect of ovariectomy or treatments was observed in the parietal cortex, striatum, nucleus accumbens, olfactory tubercle, and hippocampal CA2/3 regions (data not shown). Results are expressed in $\mathrm{fmol} / \mathrm{mg}$ of tissue \pm S.E.M. from six rats. For the cortical region, cingulate: $\mathrm{F}_{5,29}=$ $2.45, p=.05 ;{ }^{\dagger}$ estradiol-treated ovariectomized rats compared to vehicle-treated ovariectomized rats (Mean difference = 192.9, Critical difference $=187.1, p=.04$ ); tamoxifen-treated ovariectomized rats compared to vehicle-treated ovariectomized rats (Mean difference $=280.3$, Critical difference $=196.3, p=.007)$; raloxifenetreated ovariectomized compared to vehicletreated ovariectomized rats (Mean difference $=163.3$, Critical difference $=187.1$, $p=.08)$. For the cortical region, frontal: $\mathrm{F}_{5,29}=1.33, p=.27$. For the hippocampal region: $\mathrm{CA} 1: \mathrm{F}_{5,28}=1.92, p=.12$ and for the dendate gyrus: $\mathrm{F}_{5,28}=.74, p=.59$. 


\section{Cortical region}

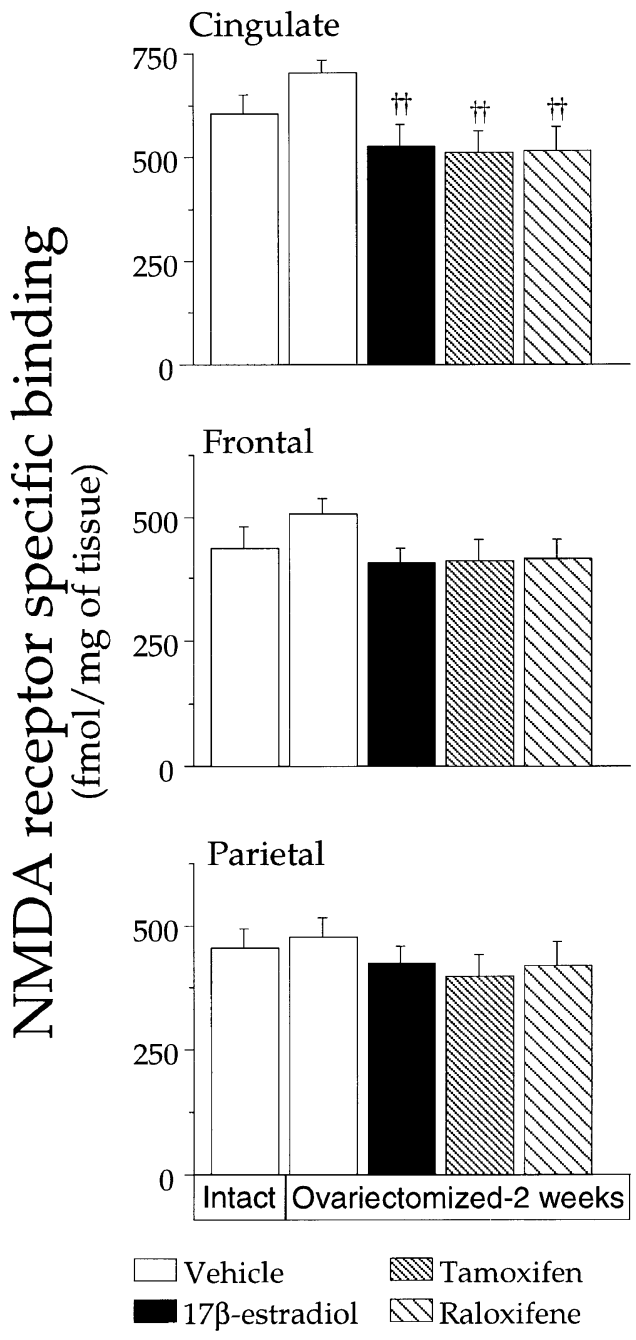

Figure 4. L- $\left[{ }^{3} \mathrm{H}\right]$ Glutamate $(0.2 \mathrm{mM})$ specific binding to NMDA receptors in cingulate, as well as frontal and parietal cortices of intact rats and two-weeks ovariectomized rats that received vehicle once daily, s.c., or a two-week replacement therapy with $17 \beta$-estradiol $(80 \mu \mathrm{g} / \mathrm{kg})$, tamoxifen $(1$ $\mathrm{mg} / \mathrm{kg})$, or raloxifene $(1 \mathrm{mg} / \mathrm{kg})$. Results are expressed in $\mathrm{fmol} / \mathrm{mg}$ of tissue \pm S.E.M. from six rats. For the cortical region, cingulate: $\mathrm{F}_{5,29}=3.49, p=.01^{\mathrm{t+}}$ estradiol-treated ovariectomized rats compared to vehicle-treated ovariectomized rats (Mean difference $=179.8$, Critical difference $=$ 128.4, $p=.007)$; tamoxifen-treated ovariectomized compared to vehicle-treated ovariectomized rats (Mean difference $=192.9$, Critical difference $=134.6, p=.006)$; and raloxifene-treated ovariectomized compared to vehicletreated ovariectomized rats (Mean difference $=190.7$, Critical difference $=128.4, p=.005)$. For the cortical region, frontal: $\mathrm{F}_{5,29}=1.88, p=.12$; and parietal $\mathrm{F}_{5,27}=0.70, p=.63$.

Oligonucleotides were $3^{\prime}$ end-labeled with terminal transferase (Boehringer Mannheim) using $20 \mathrm{pmol}$ cDNA and $50 \mu \mathrm{Ci}\left[\alpha^{-35}\right.$ S] dATP $(1200-1400 \mathrm{Ci} / \mathrm{mmol}$; NEN). Unincorporated nucleotides were removed us- ing NENSORB ${ }^{\mathrm{TM}} 20$ cartridge (NEN). All the following steps were carried out in diethylpyrocarbonate (DEPC) treated water. Brain sections were dried in a desiccator at $4^{\circ} \mathrm{C}$ and fixed in $4 \%$ paraformaldehyde in phosphate buffer $(0.1 \mathrm{M}, \mathrm{pH} 7.2)$ for $5 \mathrm{~min}$. Slides were treated by triethanolamine $(0.1 \mathrm{M}, \mathrm{pH} 8.0)$ containing $0.25 \%(\mathrm{v} / \mathrm{v})$ acetic anhydride for $10 \mathrm{~min}$ and rinsed for $30 \mathrm{~min}$ in Tris-Glycine buffer $(0.1 \mathrm{M}-0.1 \mathrm{M})$. Slides were then alcohol dehydrated and placed in a desiccator 2-3 hrs prior to in situ hybridization histochemistry. Sections were hybridized overnight at $42^{\circ} \mathrm{C}$ in a solution containing $50 \%$ formamide, $0.6 \mathrm{M} \mathrm{NaCl}, 0.06 \mathrm{M}$ sodium citrate $(4 \times$ SSC $), 10 \%$ dextran sulfate, and $15,000 \mathrm{cpm} / \mu \mathrm{l}$ of probe.

Following incubation, the brain sections were washed with $50 \%$ formamide in $2 \times$ SSC at room temperature for 1 hour, in $1 \times$ SSC at room temperature for 1 hour, in $0.5 \times \mathrm{SSC}$ at $37^{\circ} \mathrm{C}$ for $30 \mathrm{~min}$, in $0.5 \times \mathrm{SSC}$ at room temperature for $30 \mathrm{~min}$, and in $0.5 \times \mathrm{SSC}$ at $50^{\circ} \mathrm{C}$ for $30 \mathrm{~min}$. The slides were then dehydrated by consecutive washes in increasing concentrations of ethanol and air dried.

To generate autoradiograms, sections were exposed to Kodak BioMax MR film for 5-10 days. Quantification of autoradiograms were carried out by densitometry image analysis using a transmission density scale (Stouffer Graphic Arts Equipment Co. Inc, South Bend, USA) and the software package NIH Image 1.68 on a Power Macintosh 7100 assisted videodensitometry (Sony camera XC-77, lens of $65 \mathrm{~mm}$ ).

In order to evaluate NMDA receptor subunit 1 mRNA levels, the values for each group were the mean of six animals and the mean for each animal were obtained from measurements of the total area of eight adjacent sections of the cingulate, frontal, parietal, and piriform cortices, and striatum (Bregma $1.60 \mathrm{~mm}$ ) (Paxinos and Watson 1982). The measurements of the total area of eight adjacent sections of the pyramidal cell layer of the hippocampal CA1 and CA2/3 regions and the molecular layer dentate gyrus (Bregma $-4.20 \mathrm{~mm}$ ) (Paxinos and Watson 1982) were performed to evaluate NMDA receptor subunits 1,2A, and 2B mRNA levels. In situ hybridization to evaluate NMDA receptors subunits $2 \mathrm{~A}$ and $2 \mathrm{~B}$ mRNA levels in cortical and striatal regions of the brain was not performed because of the lower level of expression found in these regions (Moriyoshi et al. 1991, Monyer et al. 1992). Examples are shown in Figure 2.

\section{Statistical Analysis}

Experimental data for each brain area was compared by means of one way analysis of variance (ANOVA) using the software Statviews 4.51 for Macintosh Computer followed by post-hoc pairwise comparisons with a Fisher's probability of least significant difference test 
(PLSD). A $p<.05$ was required for the results to be considered statistically significant. Statistical comparisons of $\log$ of uterine weights were used.

\section{RESULTS}

\section{Uterine Stimulation}

There was an overall statistically significant difference in uterine weights among the experimental groups $\left(\mathrm{F}_{5,55}=\right.$ $64.732, p<.0001)$. The uterine weight of ovariectomized rats $(205 \pm 11 \mathrm{mg})$, decreased by $62 \%$ (mean difference $=$ 0.415 , critical difference $=0.063, p<.0001$ ) compared to the uterine weight of $540 \pm 47 \mathrm{mg}$ of intact non-ovariectomized rats. Estradiol treatment stimulated uterine weights of ovariectomized rats up to $461 \pm 19 \mathrm{mg}$ (compared to vehicle-treated ovariectomized rats; mean difference $=-0.355$, critical difference $=0.063, p<.0001$ ), whereas tamoxifen stimulated uterine weights of ovariectomized rats up to $265 \pm 11 \mathrm{mg}$ (compared to vehicletreated ovariectomized rats; mean difference $=-0.116$, critical difference $=0.063, p=.0005$ ) and raloxifene stim- ulated uterine weights of ovariectomized rats up to $238 \pm$ $10 \mathrm{mg}$ (compared to vehicle-treated ovariectomized rats; mean difference $=-0.068$, critical difference $=0.063, p=$ .0328), which is significantly less than estradiol compared to raloxifene (mean difference $=-0.287$, critical difference $=0.064, p<.0001$ ) and tamoxifen (mean difference $=$ -0.240 , critical difference $=0.064, p<.0001)$.

\section{L- $\left[{ }^{3} \mathrm{H}\right]$ glutamate Specific Binding}

Examples of L- $\left[{ }^{3} \mathrm{H}\right]$ glutamate binding in the cortical and hippocampal regions are shown in Figures 1 and 2. The two weeks ovariectomy was without effect in the cingulate and frontal cortices (Figure 3). Estradiol treatment decreased L- $\left[{ }^{3} \mathrm{H}\right]$ glutamate specific binding in ovariectomized rats by $16 \%(p=.04)$ in the cingulate cortex and by $10 \%$ (n.s.) in the frontal cortex compared to vehicle-treated ovariectomized rats. In cingulate cortex, tamoxifen and raloxifene mimicked the effect of estradiol and also decreased L-[ $\left.{ }^{3} \mathrm{H}\right]$ glutamate specific binding by $24 \%(p=.007)$ and by $14 \%(p=.08)$, respectively; these results did not reach statistical significance in the frontal cortex (Figure 2). In the hippocampal CA1

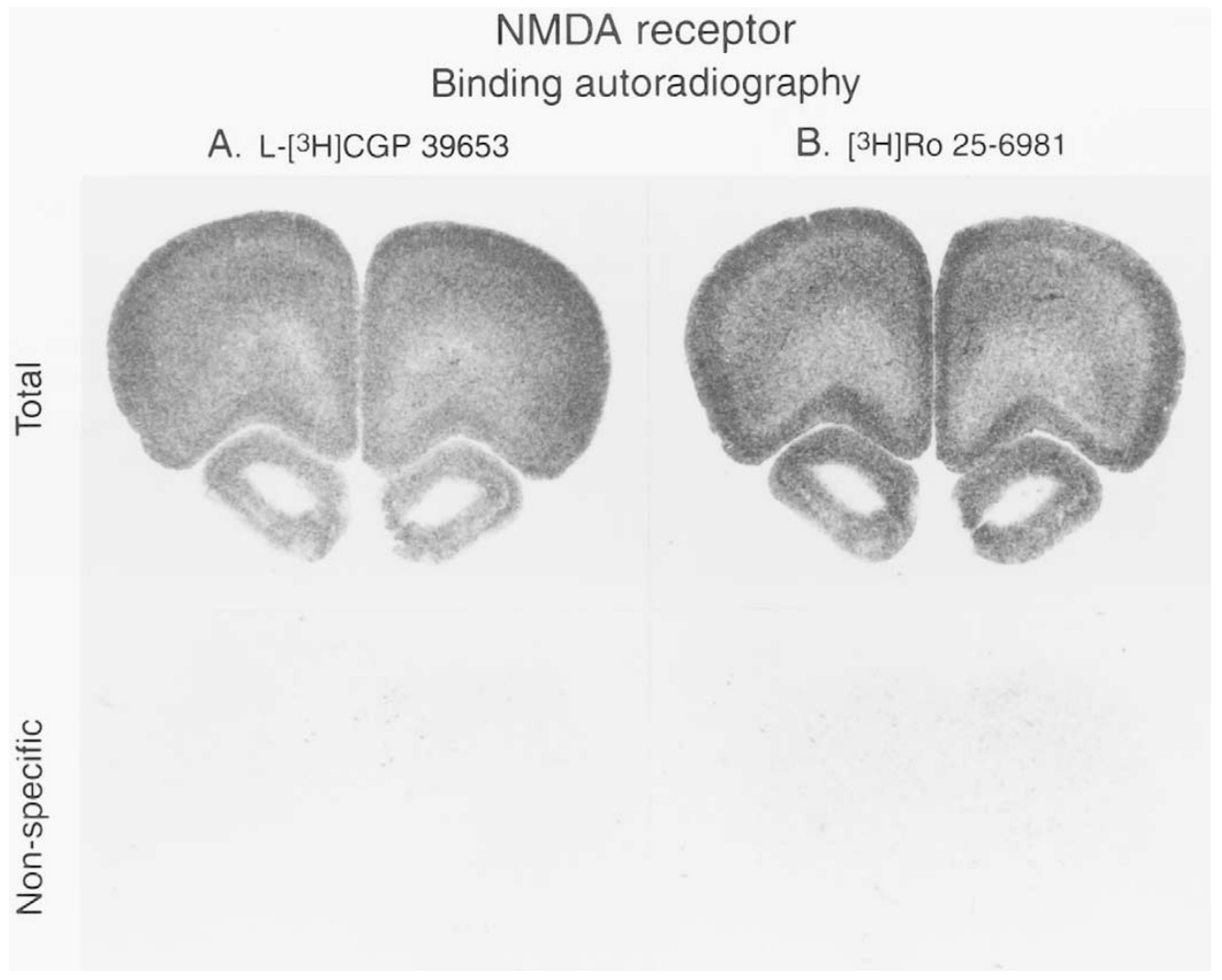

Figure 5. Examples of binding autoradiography using (A) L- $\left[{ }^{3} \mathrm{H}\right] \mathrm{CGP} 39653(20 \mathrm{nM})$ binding to NMDA receptor subunits $1 / 2 \mathrm{~A}$ or $(\mathbf{B})\left[{ }^{3} \mathrm{H}\right]$ Ro $25-6981(5 \mathrm{nM})$ binding to NMDA receptor subunits $1 / 2 \mathrm{~B}$ in rostral brain regions (Bregma 4.20, Paxinos and Watson, 1982) of intact rats. Non-specific binding was determined by adding $0.5 \mathrm{mM}$ L-NMDA or $10 \mu \mathrm{M}$ Ro $04-5595$ hydrochloride to the incubation buffer for binding of L- $\left[{ }^{3} \mathrm{H}\right] \mathrm{CGP} 39653$ and $\left[{ }^{3} \mathrm{H}\right] \mathrm{Ro} 25-6981$, respectively. Non-specific binding of L- $\left[{ }^{3} \mathrm{H}\right]$ CGP 39653 and $\left[{ }^{3} \mathrm{H}\right]$ Ro 25-6981 were practically undetectable on film autoradiograms under our experimental conditions (see Materials and Methods). 
and dendate gyrus regions, the effect of ovariectomy and hormonal treatment did not reach statistical significance (Figure 3). Similarly, no effect of ovariectomy or treatments were observed in parietal cortex, striatum, nucleus accumbens, olfactory tubercle, and in the hippocampal CA2/3 regions (data not shown).

\section{NMDA Receptors Specific Binding}

Cortical Region. The two weeks ovariectomy was without significant effect on the NMDA receptor specific binding in all of the cortices assayed. Estradiol treatment in ovariectomized rats decreased this receptor binding of $26 \%$ in the cingulate cortex $(p=.007)$ and this effect faded when moving towards the frontal cortex $(20 \%)$ and the parietal cortex $(11 \%)$ (Figure 4$)$. In ovariectomized rats, tamoxifen as well as raloxifene treatments mimicked the effects of estradiol treatment and decreased significantly NMDA receptor specific binding in the cingulate cortex and left unchanged this receptor binding in the frontal and parietal cortices (Figure 4).

We focused our experiments to the cingulate cortex to determine the effect of hormonal modulation on the NMDA competitive antagonist site; the cingulate cortex is the cortex where greatest effects of ovariectomy and treatments were observed (Figure 4). Examples of total and non-specific binding of L-[ $\left.{ }^{3} \mathrm{H}\right] \mathrm{CGP} 39653$ and $\left[{ }^{3} \mathrm{H}\right]$ Ro $25-6981$ in the rostral cortical region are shown in Figure 5. The specific binding of L- $\left[{ }^{3} \mathrm{H}\right] \mathrm{CGP} 39653$ was not affected by ovariectomy and treatments in the anterior cingulate cortex whereas the specific binding of $\left[{ }^{3} \mathrm{H}\right]$ Ro 25-6981 was not affected by ovariectomy, but decreased by $15 \%$ after estradiol treatments $(p=.0002)$ and by $8 \%$ after tamoxifen and raloxifene treatments $(p=$ .02 and .03 , respectively) (Figure 6).

Striatal Region. A similar density was measured in the dorsal part ( $315 \pm 33 \mathrm{fmol} / \mathrm{mg}$ of tissue) of the striatum compared to the ventral part (354 $\pm 39 \mathrm{fmol} / \mathrm{mg}$ of tissue). Ovariectomy and hormonal treatments gave similar results in the dorsal and ventral striatum. Therefore, the results of the total striatum are presented. Ovariectomy in rats left NMDA binding unchanged in the striatum and nucleus accumbens (Figures 1 and 7). Estradiol, tamoxifen, and raloxifene treatments decreased NMDA receptor binding similarly in the striatum and nucleus accumbens of ovariectomized rats (Figure 7). Ovariectomy and treatments were without effects on the NMDA receptor binding density in olfactory tubercle of ovariectomized rats (Figure 7).

Hippocampal Region. In contrast to the other brain regions assayed, ovariectomy decreased NMDA receptor specific binding density by $35 \%$ in the CA1 region and by $29 \%$ in the dentate gyrus of the hippocampus ( $p=$ .01 and .02, respectively) (Figure 8). Estradiol, tamoxifen, and raloxifene treatments prevented the ovariec-

\section{Anterior cingulate cortex}
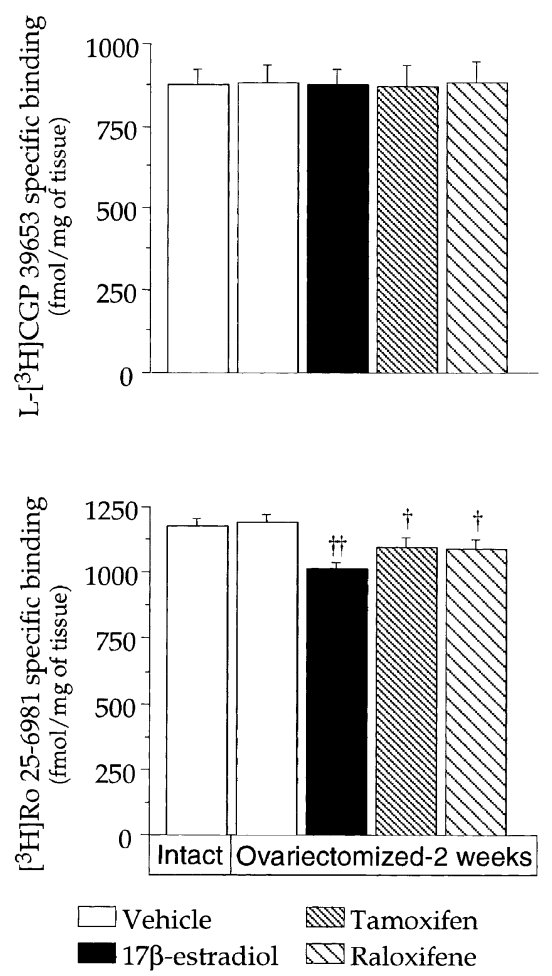

Figure 6. L- $\left[{ }^{3} \mathrm{H}\right] \mathrm{CGP} 39653(20 \mathrm{nM})$ and $\left[{ }^{3} \mathrm{H}\right]$ Ro 25-6981 (5 $\mathrm{nM})$ specific binding in anterior cingulate cortex of intact rats as well as two-weeks ovariectomized rats that received vehicle once daily, s.c., or a two-week replacement therapy with $17 \beta$-estradiol $(80 \mu \mathrm{g} / \mathrm{kg})$, tamoxifen $(1 \mathrm{mg} / \mathrm{kg})$, or raloxifene $(1 \mathrm{mg} / \mathrm{kg})$. Results are expressed in $\mathrm{fmol} / \mathrm{mg}$ of tissue \pm S.E.M. from nine rats. For L- $\left[{ }^{3} \mathrm{H}\right]$ CGP 39653 binding: $\mathrm{F}_{5,40}=0.023, p=.99$. For $\left[{ }^{3} \mathrm{H}\right]$ Ro $25-6981$ binding: $\mathrm{F}_{5,37}=$ $4.98, p=.001{ }^{\text {+ो }}$ estradiol-treated ovariectomized rats compared to vehicle-treated ovariectomized rats (Mean difference $=179.7$, Critical difference $=86.6, p=.0002){ }^{\dagger}$ tamoxifen-treated ovariectomized compared to vehicletreated ovariectomized rats (Mean difference $=99.1$, Critical difference $=86.6, p=.02$ ); and raloxifene-treated ovariectomized compared to vehicle-treated ovariectomized rats (Mean difference $=101.9$, Critical difference $=93.5, p=.03$ ) .

tomy induced decrease of NMDA receptor specific binding observed in these regions (Figure 8). No significant effects of ovariectomy or treatments on NMDA receptor specific binding were observed in hippocampal $\mathrm{CA} 2 / 3$ regions (Figure 8 ).

The hippocampal L- $\left[{ }^{3} \mathrm{H}\right]$ CGP 39653 specific binding was not affected by ovariectomy and treatments (Figure 9). In contrast, $\left[{ }^{3} \mathrm{H}\right]$ Ro $25-6981$ specific binding decreased by $16 \%$ after ovariectomy in the oriens ( $p=$ .004 ) and by $17 \%$ in the stratum radiatum layers of hippocampal CA1 region ( $p=.01)$; estradiol, tamoxifen, and raloxifene treatments prevented the ovariectomy induced decrease of this binding (Figures 9 and 10, Ta- 


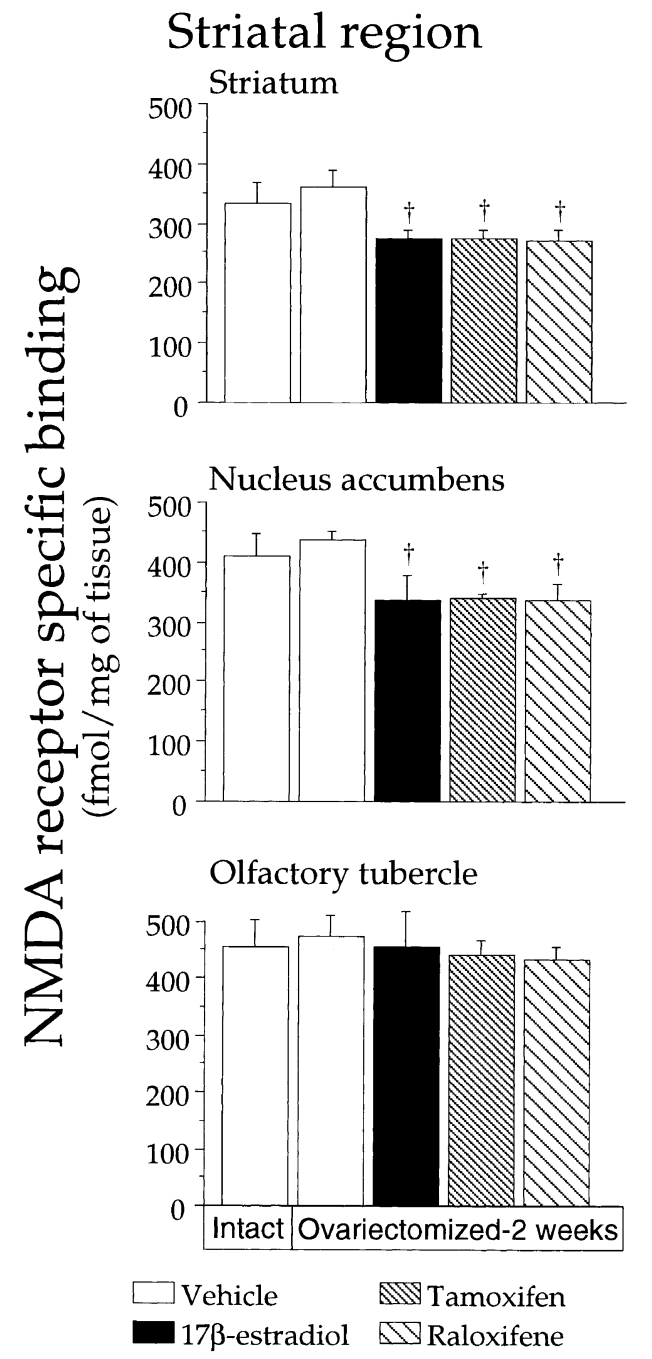

Figure 7. L- $\left[{ }^{3} \mathrm{H}\right]$ Glutamate $(0.2 \mathrm{mM})$ specific binding to NMDA receptors in striatum, nucleus accumbens, and olfactory tubercle of intact rats as well as two-weeks ovariectomized rats that received vehicle once daily, s.c., or a twoweek replacement therapy with $17 \beta$-estradiol $(80 \mu \mathrm{g} / \mathrm{kg})$, tamoxifen $(1 \mathrm{mg} / \mathrm{kg})$, or raloxifene $(1 \mathrm{mg} / \mathrm{kg})$. Results are expressed in $\mathrm{fmol} / \mathrm{mg}$ of tissue \pm S.E.M. from six rats. For striatum: $\mathrm{F}_{5,29}=3.29, p=.01{ }^{\dagger}{ }^{\dagger}$ estradiol-treated ovariectomized rats compared to vehicle-treated ovariectomized rats (Mean difference $=86.1$, Critical difference $=63.9, p=.01$ ); tamoxifen-treated ovariectomized compared to vehicletreated ovariectomized rats (Mean difference $=84.7$, Critical difference $=67.0, p=.01$ ) and raloxifene-treated ovariectomized compared to vehicle-treated ovariectomized rats (Mean difference $=88.6$, Critical difference $=63.9, p=.008$ ) . For nucleus accumbens: $\mathrm{F}_{5,29}=2.67, p=.04 ;^{+}$estradioltreated ovariectomized rats compared to vehicle-treated ovariectomized rats (Mean difference $=98.8$, Critical difference $=79.0, p=.01)$; tamoxifen-treated ovariectomized compared to vehicle-treated ovariectomized rats (Mean difference $=96.1$, Critical difference $=82.9, p=.02$ ); and raloxifene-treated ovariectomized compared to vehicle-treated ovariectomized rats (Mean difference $=100.5$, Critical difference $=79.0, p=.01$ ). For olfactory tubercle: $\mathrm{F}_{5,29}=0.10, p=.99$.

\section{Hippocampal region}

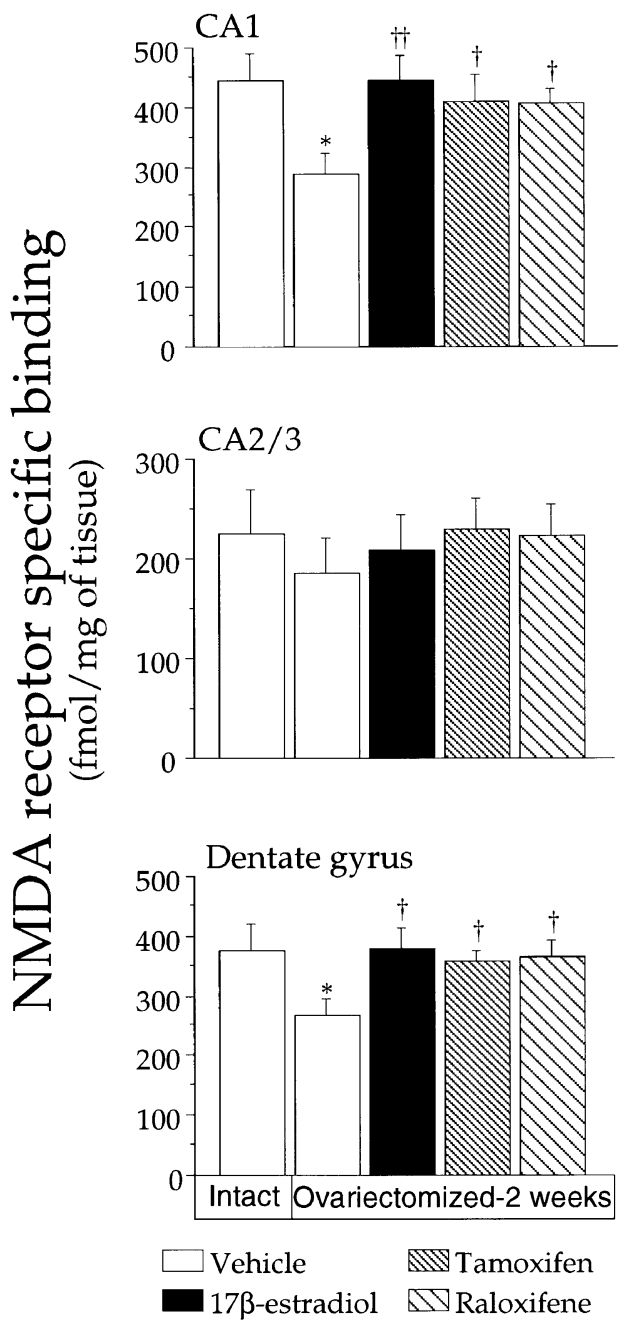

Figure 8. L- $\left[{ }^{3} \mathrm{H}\right]$ Glutamate $(0.2 \mathrm{mM})$ specific binding to NMDA receptors in hippocampal CA1, CA2/3, and dentate gyrus regions of intact rats as well as two-weeks ovariectomized rats that received vehicle once daily, s.c., or a two-week replacement therapy with $17 \beta$-estradiol $(80 \mu \mathrm{g} / \mathrm{kg})$, tamoxifen $(1 \mathrm{mg} / \mathrm{kg})$, or raloxifene $(1 \mathrm{mg} / \mathrm{kg})$. Results are expressed in $\mathrm{fmol} / \mathrm{mg}$ of tissue \pm S.E.M. from six rats. For the hippocampal region, $\mathrm{CA} 1: \mathrm{F}_{5,28}=3.46, p=.01$, ${ }^{*}$ vehicle-treated ovariectomized compared to intact rats (Mean difference $=156.7$, Critical difference $=118.2, p=.01) ;{ }^{\text {t+ }}$ estradiol-treated ovariectomized rats compared to vehicle-treated ovariectomized rats (Mean difference $=-157.1$, Critical difference $=112.7, p=$ $.008) ;{ }^{\dagger}$ tamoxifen-treated ovariectomized compared to vehicletreated ovariectomized rats (Mean difference $=-119.3$, Critical difference $=118.2, p=.04$ ); and raloxifene-treated ovariectomized compared to vehicle-treated ovariectomized rats (Mean difference $=-122.6$, Critical difference $=112.7, p=.03$ ). For the hippocampal region, $\mathrm{CA} 2 / 3: \mathrm{F}_{5,28}=0.20, p=.95$. For the hippocampal region, dendate gyrus: $\mathrm{F}_{5,28}=2.79, p=.03$, * vehicle-treated ovariectomized compared to intact rats (Mean difference $=107.8$, Critical difference $=93.0, p=.02){ }^{\dagger}{ }^{\dagger}$ estradiol-treated ovariectomized rats compared to vehicle-treated ovariectomized rats (Mean difference $=-112.8$, Critical difference $=88.7, p=.01$ ); tamoxifen-treated ovariectomized compared to vehicle-treated ovariectomized rats (Mean difference $=$ -96.3, Critical difference $=93.0, p=.04$ ); and raloxifene-treated ovariectomized compared to vehicle-treated ovariectomized rats $($ Mean difference $=-89.3$, Critical difference $=88.7, p=.04$ ). 


\title{
Hippocampal region
}

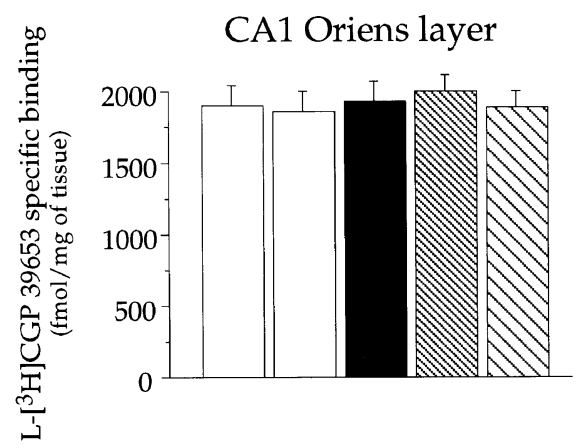

\author{
CA1 Stratum Radiatum
}

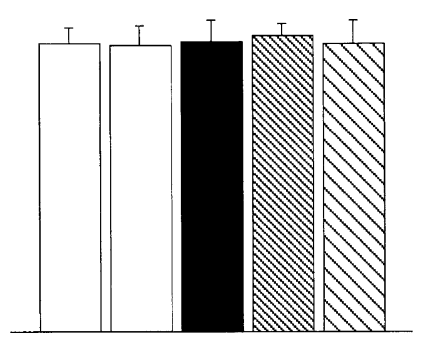

Dentate gyrus
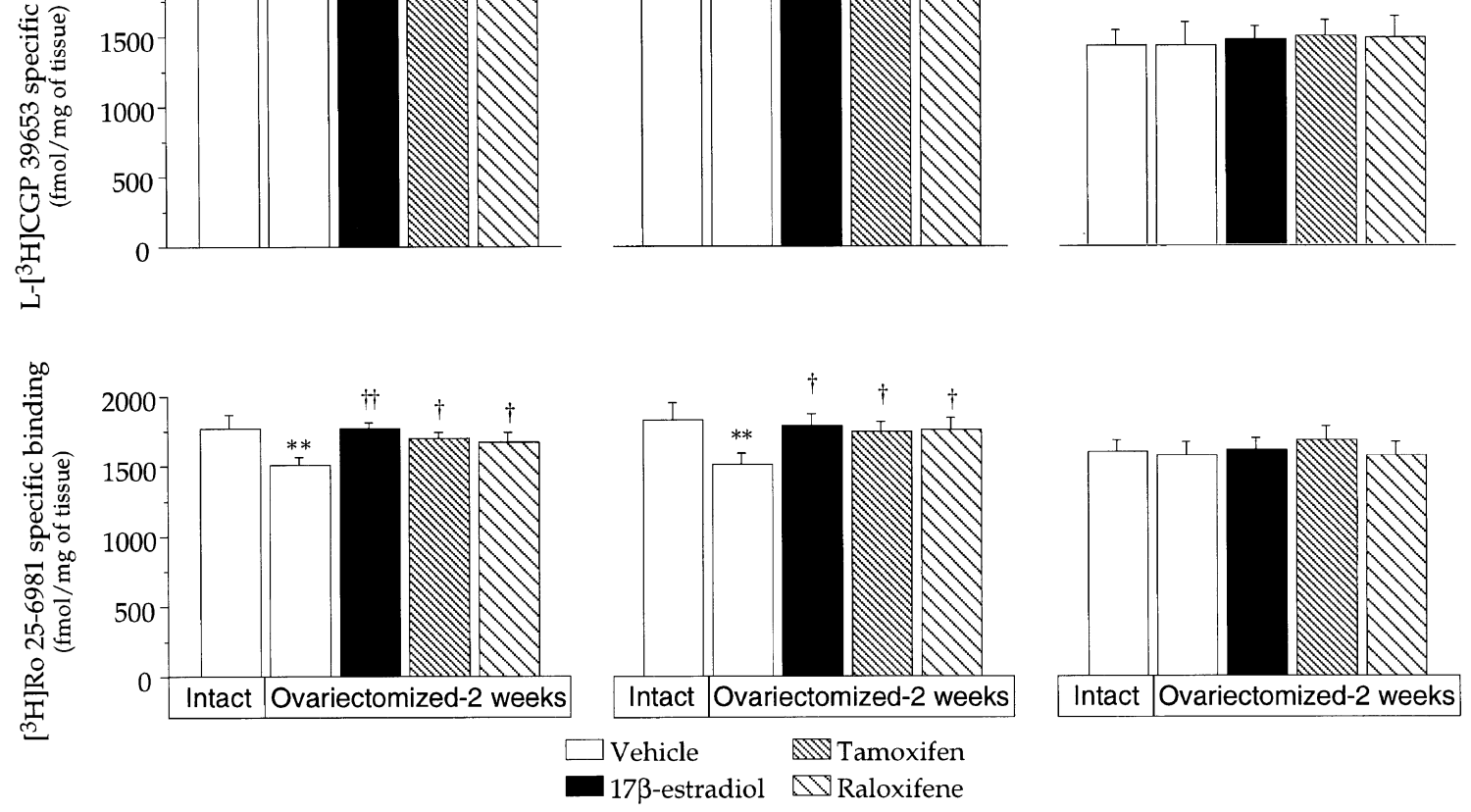

Figure 9. L-[ $\left[{ }^{3} \mathrm{H}\right] \mathrm{CGP} 39653(20 \mathrm{nM})$ and $\left[{ }^{3} \mathrm{H}\right] \mathrm{Ro} 25-6981(5 \mathrm{nM})$ specific binding in oriens layer and stratum radiatum of the hippocampal CA1 region as well as the molecular layer dentate gyrus in intact rats and two-weeks ovariectomized rats that received vehicle once daily, s.c., or a two-week replacement therapy with $17 \beta$-estradiol $(80 \mu \mathrm{g} / \mathrm{kg})$, tamoxifen $(1 \mathrm{mg} / \mathrm{kg})$, or raloxifene $(1 \mathrm{mg} / \mathrm{kg})$. Results are expressed in fmol $/ \mathrm{mg}$ of tissue \pm S.E.M. from nine rats. For L- $\left.{ }^{3} \mathrm{H}\right]$ CGP 39653 binding, CA1 oriens layer: $\mathrm{F}_{5,19}=0.12, p=.98, \mathrm{CA} 1$ Stratum Radiatum: $\mathrm{F}_{5,19}=0.02, p=.99$, and Dendate gyrus: $\mathrm{F}_{5,19}=0.06, p=.99$. For $\left[{ }^{3} \mathrm{H}\right]$ Ro 25-6981 binding, CA1 oriens layer: $\mathrm{F}_{5,33}=3.50, p=.01,{ }^{* *}$ vehicle-treated ovariectomized compared to intact rats (Mean difference $=281.7$, Critical difference $=188.3, p=.004) ;{ }^{\text {t+ }}$ estradiol-treated ovariectomized rats compared to vehicle-treated ovariectomized rats (Mean difference $=-255.6$, Critical difference $=166.4, p=.003$ ) ${ }^{{ }^{+}}$tamoxifen-treated ovariectomized compared to vehicle-treated ovariectomized rats (Mean difference $=-192.9$, Critical difference $=188.3, p=.04$ ); and raloxifene-treated ovariectomized compared to vehicle-treated ovariectomized rats (Mean difference $=-172.7$, Critical difference $=171.8, p=.04$ ); CA1 Stratum Radiatum: $\mathrm{F}_{5,32}=2.56, p=.04,{ }^{* *}$ ovariectomized compared to intact rats (Mean difference $=314.1$, Critical difference $=245.3, p=.01) ;{ }^{\dagger}$ estradiol-treated ovariectomized rats compared to vehicle-treated ovariectomized rats (Mean difference $=$ -273.3 , Critical difference $=216.8, p=.01$ ); tamoxifen-treated ovariectomized compared to vehicle-treated ovariectomized rats (Mean difference $=-243.9$, Critical difference $=245.3, p=.05$ ); and raloxifene-treated ovariectomized compared to vehicletreated ovariectomized rats (Mean difference $=-245.9$, Critical difference $=233.1, p=.03$ ); Dendate gyrus : $\mathrm{F}_{5,34}=0.26, p=.93$.

ble 1). Specific binding of $\left[{ }^{3} \mathrm{H}\right] \mathrm{Ro}$ 25-6981 was not affected by ovariectomy or treatments in the oriens or radiatum layers of the hippocampal $\mathrm{CA} 2 / 3$ regions (Table 1) or in the dentate gyrus (Figure 10).

\section{NMDA Receptors mRNA Levels}

The mRNA levels encoding the NMDA receptors subunit 1 were not affected by ovariectomy and treatments in the cingulate, frontal, parietal, and piriform cortices (data not shown). The level of NMDA receptor subunit 1 mRNA expression in the striatum was weak but strong enough for quantification and no effect of ovariectomy and treatments were observed in this region (data not shown). Ovariectomy decreased mRNA levels of the NMDA receptor subunits 1 and $2 \mathrm{~B}(25 \%, p=.003$ and $21 \%, p=.002$, respectively) only in the hippocampal CA1 region, whereas the other regions of hippocampus were not significantly affected (Figure 11, Table 1). Estradiol treatment prevented the ovariectomy induced decrease of mRNA levels of NMDA receptor subunits 1 and $2 \mathrm{~B}$ in the CA1 (Figure 11). Similarly, tamoxifen and raloxifene treatments prevented, in the CA1, the ovariectomy induced decrease of mRNA expression of the NMDA receptor subunit 1 , that is respectively $20 \%(p=.05)$ and $22 \%(p=.03)$ higher than ovariectomized rats, whereas they had no significant effect on the mRNA levels of subunit $2 \mathrm{~B}(10 \%, p=.20$ and $15 \%, p=.06$, respectively). Ovariectomy and treatments were without effect on mRNA levels of the 


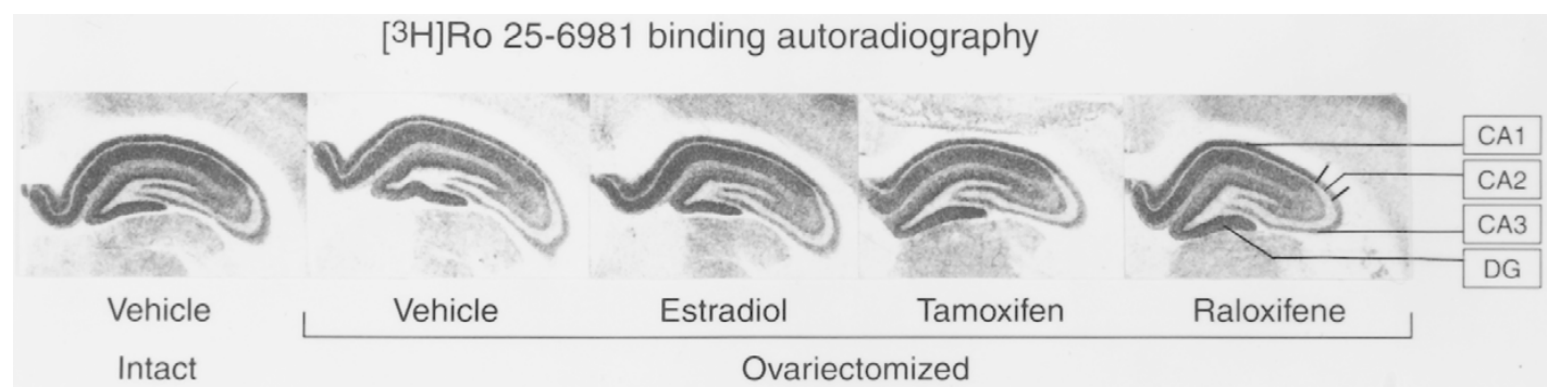

Figure 10. Autoradiograms of coronal brain sections showing binding of $\left[{ }^{3} \mathrm{H}\right]$ Ro $25-6981$ (5 nM) to the NMDA receptor subunits 1 and 2B in hippocampal regions [Bregma -4.16 (Paxinos and Watson 1982)] of intact rats and two-weeks ovariectomized rats that received vehicle once daily, s.c., or a two-week replacement therapy with $17 \beta$-estradiol $(80 \mu \mathrm{g} / \mathrm{kg})$, tamoxifen $(1 \mathrm{mg} / \mathrm{kg})$, or raloxifene $(1 \mathrm{mg} / \mathrm{kg})$. Abbreviations: CA1, CA2, and CA3: fields CA1, CA2, and CA3 of hippocampus; DG: dentate gyrus.

NMDA receptor subunit $2 \mathrm{~A}$ in the hippocampal regions assayed (Figure 11, Table 1) and also, were without effect on mRNA levels of the NMDA receptor subunits 1 and $2 \mathrm{~B}$ in the pyramidal cell layer of hippocampal CA2/3 regions (Table 1 ).

\section{DISCUSSION}

L- $\left[{ }^{3} \mathrm{H}\right]$ glutamate binds to all of the excitatory amino acid receptors including ionotropic (NMDA, AMPA, and kainate) and metabotropic (mGLU 1 to mGLU 7) receptors as well as to the glutamate transporter. The L- $\left[{ }^{3} \mathrm{H}\right]$ glutamate specific binding thus gives an overall picture of the glutamate receptor subtypes and transporter. Our experiments showed that two weeks replacement therapy with estradiol decreased L- $\left[{ }^{3} \mathrm{H}\right]$ glutamate specific binding in cingulate cortex, but not in the frontal or the parietal cortices. This confirms the regional specificity in the brain of estradiol on glutamate receptors that we previously reported (Cyr et al. 2000a) and further refines the effect in the rostral cortex which is mostly in the cingulate cortex. NMDA receptors and $\mathrm{L}-\left[{ }^{3} \mathrm{H}\right]$ glutamate specific binding displayed a parallel pattern of changes after ovariectomy and estradiol treatment in the cingulate cortex, suggesting that the NMDA receptor is one of the glutamate receptor subtypes implicated in the hormonal modulation of $\mathrm{L}-\left[{ }^{3} \mathrm{H}\right]$ glutamate specific binding. We have previously found a parallel pattern of changes in NMDA receptors and L- $\left[{ }^{3} \mathrm{H}\right]$ glutamate specific binding in the cortical regions after ovariectomy and estradiol treatment (Cyr et al. 2000a).

[ $\left.{ }^{3} \mathrm{H}\right]$ Ro 25-6981 specific binding further supports the concept that ovariectomy and estradiol can regulate NMDA receptor subunit binding in the hippocampus and frontal cortex, whereas L-[3H]CGP 39653 specific binding suggest no hormonal modulation on this recep-

Table 1. L- $\left[{ }^{3} \mathrm{H}\right]$ CGP $39653(20 \mathrm{nM})$ and $\left[{ }^{3} \mathrm{H}\right]$ Ro $25-6981(5 \mathrm{nM})$ specific binding, as well as in situ hybridization of NMDA receptor subunits $1,2 \mathrm{~A}$, and $2 \mathrm{~B}$ in hippocampal CA2/3 subregion of intact rats and ovariectomized rats (two weeks) receiving vehicle (once daily, s.c.) or a replacement therapy of two weeks with $17 \beta$-estradiol $(80 \mu \mathrm{g} / \mathrm{kg})$, tamoxifen $(1 \mathrm{mg} / \mathrm{kg})$, or raloxifene $(1 \mathrm{mg} / \mathrm{kg})$.

\begin{tabular}{|c|c|c|c|c|c|c|c|}
\hline \multirow[b]{3}{*}{ GROUP } & \multicolumn{4}{|c|}{$\begin{array}{l}\text { Specific Binding of NMDA Receptor } \\
\text { (fmol/mg of tissue) }\end{array}$} & \multicolumn{3}{|c|}{$\begin{array}{l}\text { mRNA levels of NMDA Receptor Subunit } \\
\text { (Relative Optical Density) }\end{array}$} \\
\hline & \multicolumn{2}{|c|}{ L- $\left[{ }^{3} \mathrm{H}\right]$ CGP 39653} & \multicolumn{2}{|c|}{$\left[{ }^{3} \mathrm{H}\right]$ Ro $25-6981$} & 1 & $2 \mathrm{~A}$ & 2B \\
\hline & Oriens & Radiatum & Oriens & Radiatum & \multicolumn{3}{|c|}{ Pyramidal Cell Layer } \\
\hline Intact + Vehicle & $1155 \pm 106$ & $1252 \pm 79$ & $1002 \pm 58$ & $1033 \pm 58$ & $0.320 \pm 0.009$ & $0.095 \pm 0.03$ & $0.069 \pm 0.002$ \\
\hline Ovariectomized + Vehicle & $1124 \pm 67$ & $1242 \pm 71$ & $940 \pm 56$ & $981 \pm 54$ & $0.316 \pm 0.023$ & $0.094 \pm 0.002$ & $0.064 \pm 0.004$ \\
\hline Ovariectomized + Estradiol & $1130 \pm 102$ & $1253 \pm 99$ & $965 \pm 49$ & $1024 \pm 47$ & $0.319 \pm 0.024$ & $0.093 \pm 0.002$ & $0.069 \pm 0.005$ \\
\hline Ovariectomized + Tamoxifen & $1141 \pm 30$ & $1273 \pm 55$ & $986 \pm 47$ & $1114 \pm 92$ & $0.330 \pm 0.016$ & $0.093 \pm 0.007$ & $0.068 \pm 0.004$ \\
\hline Ovariectomized + Raloxifene & $1181 \pm 106$ & $1274 \pm 94$ & $946 \pm 63$ & $1006 \pm 62$ & $0.327 \pm 0.022$ & $0.095 \pm 0.003$ & $0.069 \pm 0.005$ \\
\hline
\end{tabular}

Results are expressed in fmol/mg of tissue \pm S.E.M. of four rats in each group for the L- $\left[{ }^{3} \mathrm{H}\right]$ CGP 39653 binding experiment except for the Ovariectomized + Estradiol group which included five rats; the $\left[{ }^{3} \mathrm{H}\right]$ Ro $25-6981$ binding experiment included six Intact + Vehicle, seven Ovariectomized + Vehicle, eight Ovariectomized + Estradiol, five Ovariectomized + Tamoxifen, and seven Ovariectomized + Raloxifene treated rats; determination of mRNA levels of NMDA receptor subunits 1,2A, and 2B included six rats in each treatment group. 


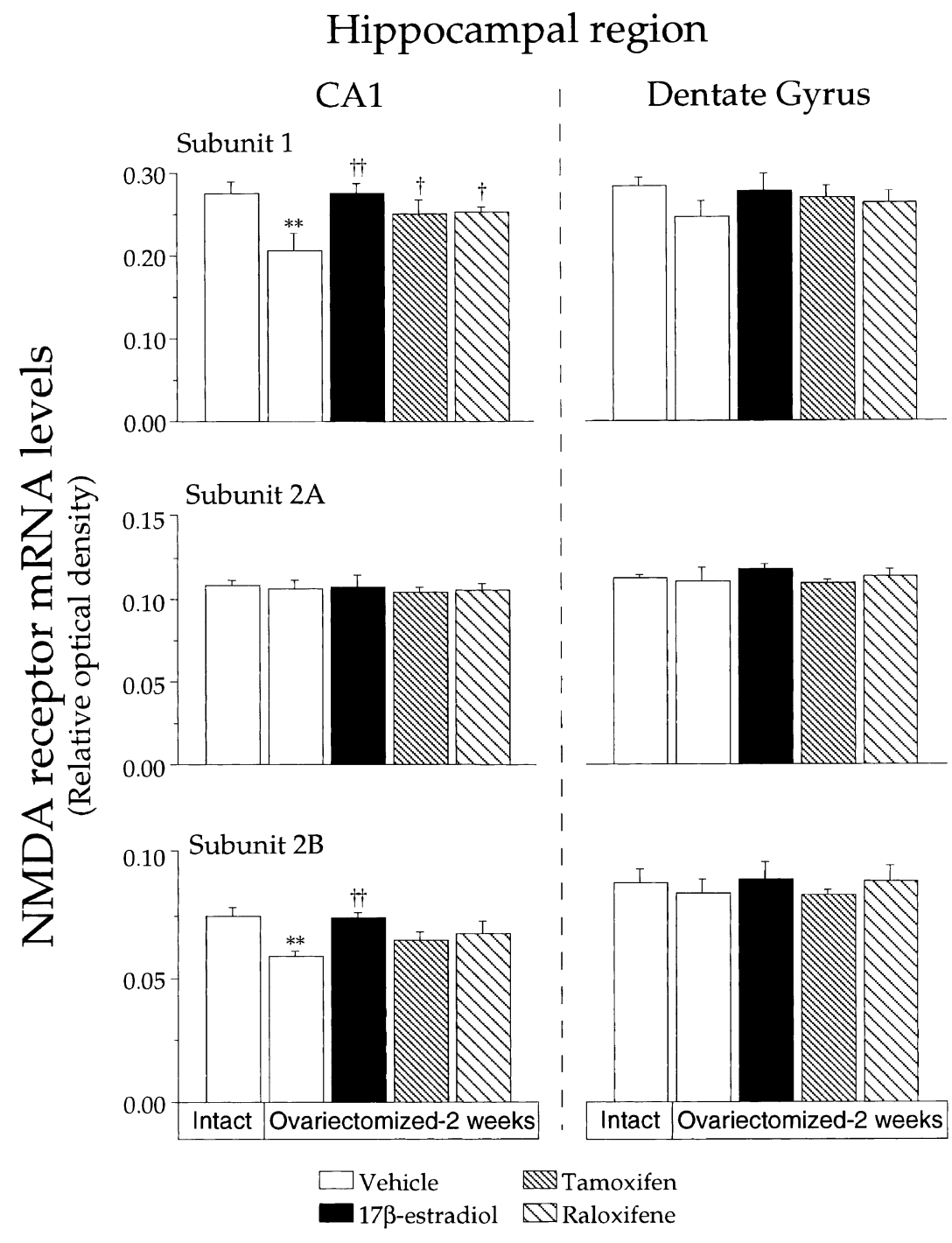

Hippocampal region

tor subunit binding. A possible explanation of this difference is the binding site of these ligands. Indeed, L- $\left[{ }^{3} \mathrm{H}\right] \mathrm{CGP} 39653$ has more affinity to the glutamate agonist site of NMDA receptors (Sills et al. 1991), whereas $\left[{ }^{3} \mathrm{H}\right]$ Ro $25-6981$ has more affinity to the polyamine site (Fischer et al. 1997). Our results are in agreement with a previous report showing no effect of estradiol on L- $\left[{ }^{3} \mathrm{H}\right]$ CGP 39653 specific binding in the hippocampal regions of ovariectomized rats (Weiland 1992). Furthermore, the difference between intact and ovariectomized rats observed in the hippocampus is supported by the recent finding that NMDA receptor changes during the estrous cycle (Lu et al. 2000). So far, it has been shown that specific L- $\left[{ }^{3} \mathrm{H}\right] \mathrm{CGP} 39653$ binding is possible only when subunit NMDA receptor $2 \mathrm{~A}$ is present in the het-
Figure 11. In situ hybridization of NMDA receptor subunits $1,2 \mathrm{~A}$, and $2 \mathrm{~B}$ in hippocampal CA1, and dentate gyrus regions of intact rats as well as two-weeks ovariectomized rats that received vehicle once daily, s.c., or a two-week replacement therapy with $17 \beta$-estradiol $(80 \mu \mathrm{g} / \mathrm{kg})$, tamoxifen (1 $\mathrm{mg} / \mathrm{kg})$, or raloxifene $(1 \mathrm{mg} / \mathrm{kg})$. Results are expressed in relative optical density \pm S.E.M. from six rats. For CA1, subunit 1: $\mathrm{F}_{5,29}=3.75, p=.009,{ }^{* *}$ vehicle-treated ovariectomized compared to intact rats (Mean difference $=0.069$, Critical difference $=$ $0.043, p=.002){ }^{\text {t+ }}$ estradiol-treated ovariectomized rats compared to vehicle-treated ovariectomized rats (Mean difference $=$ -0.068 , Critical difference $=0.043, p=$ $.003) ;{ }^{\dagger}$ tamoxifen-treated ovariectomized compared to vehicle-treated ovariectomized rats (Mean difference $=-0.043$, Critical difference $=0.043, p=.05$ ); and raloxifenetreated ovariectomized compared to vehicletreated ovariectomized rats (Mean difference $=-0.046$, Critical difference $=0.043$, $p=.03$ ); for CA1, subunit $2 \mathrm{~A}: \mathrm{F}_{5,30}=0.08$, $p=.99$ and $\mathrm{CA} 1$, subunit $2 \mathrm{~B}: \mathrm{F}_{5,29}=5.30, p=$ $.001,{ }^{* *}$ vehicle-treated ovariectomized compared to intact rats (Mean difference $=$ 0.016 , Critical difference $=0.010, p=.002$ ); ${ }^{++}$estradiol-treated ovariectomized rats compared to vehicle-treated ovariectomized rats (Mean difference $=-0.015$, Critical difference $=0.010, p=.003$ ); tamoxifen-treated ovariectomized compared to vehicle-treated ovariectomized rats (Mean difference $=$ -0.006 , Critical difference $=0.010, p=.20$ ); and raloxifene-treated ovariectomized compared to vehicle-treated ovariectomized rats (Mean difference $=-0.009$, Critical difference $=0.010, p=.06)$. For Dendate gyrus, subunit $1: \mathrm{F}_{5,29}=0.87, p=.51$; subunit $2 \mathrm{~A}$ : $\mathrm{F}_{5,30}=0.47, p=.79$; and subunit $2 \mathrm{~B}: \mathrm{F}_{5,29}=$ $0.21, p=.95$. eromeric receptor (Marti et al. 1993; Lynch et al 1994; Laurie and Seeburg 1994; Mugnaini et al. 1996).

In a more recent study, L- $\left[{ }^{3} \mathrm{H}\right]$ CGP 39653 is shown to label two pharmacologically distinct populations of NMDA receptors that have pharmacologically and anatomical properties consistent with NMDA receptor subunits $2 \mathrm{~A}$ and $2 \mathrm{~B}$ (Christie et al. 2000). In contrast, $\left[{ }^{3} \mathrm{H}\right] \mathrm{Ro}$ 25-6981 demonstrates a high affinity for the NMDA receptor containing subunit 2B (Fischer et al. 1997; Mutel et al. 1998) and the distribution of its binding sites correlates well with that of NMDA receptor subunit 2B transcripts, but not with subunit 2A (Mutel et al. 1998). These properties of $\left[{ }^{3} \mathrm{H}\right]$ Ro $25-6981$, in addition to our results suggest that the hormonal modulation of NMDA agonist binding sites may be a reflection of the 
total number of heteromeric NMDA receptor subunits, with higher implication of subunit 2B.

Other glutamate receptor subtypes than NMDA receptors could be implicated positively or negatively in the hormonal modulation of the L- $\left[{ }^{3} \mathrm{H}\right]$ glutamate specific binding reported so far. Indeed, previous results have demonstrated that non-NMDA receptors such as AMPA receptors can be similarly influenced by estradiol in cortical (Cyr et al. 2000a) but not in hippocampal regions (Weiland 1992; Cyr et al. 2000) or overexpressed in the hypothalamus (Gu et al. 1999). Moreover, it has been reported that the kainate receptor, another non-NMDA receptor, is not influenced by estradiol (Weiland 1992). Very little studies have yet directly assessed the influence of sex steroids on the different subtypes of glutamate receptors. The lack of effect on L- $\left[{ }^{3} \mathrm{H}\right]$ glutamate specific binding after ovariectomy or estradiol treatment in the hippocampus, striatum, and nucleus accumbens may be due to the combined hormonal effect on various glutamate receptor subtypes. This research area needs further investigation in order to clearly understand the exact mechanism of the effect of sex steroids on brain glutamate receptors.

In the CA1 subregion of the hippocampus, our in situ hybridization experiments showed that subunits 1 and $2 \mathrm{~B}$, but not $2 \mathrm{~A}$, decreased after ovariectomy and that this decrease was prevented by hormonal treatments. These results suggest the implication of a genomic mechanism of action in this specific region of the hippocampus. It has to be noted that our evaluation of the NMDA receptor subunit 1 mRNA reflects a pool of eight potential isoforms in all regions studied (Sugihara et al. 1992; Hollmann et al. 1993). Previous results have also suggested the implication of a classical genomic mechanism of action. It was reported in two studies (Brann et al. 1993; Gu et al. 1999) that estradiol influences mRNA levels of the NMDA receptor subunit 1 , whereas another study showed no effect (Gazzaley et al. 1996). These discrepancies may be due to differences in age, sex, or hormonal treatment paradigms. For example, the estrogen dosage used is higher $(20 \mu \mathrm{g} /$ day / 14 days) and the period of treatment, longer in our studies, compared to the dosage and time (two days) used in the study of Gazzaley et al. (1996) who reported no effect of estradiol. The genomic mechanism of action may be through the intracellular estrogen receptor which has been found in the hippocampus by several methods (Pfaff and Keiner 1973; Loy et al. 1988; Maggi et al. 1989).

More recently, both $\alpha$ and $\beta$ estrogen receptors have been found by immunohistochemistry and in situ hybridization in the hippocampus, located in greatest concentration in the hilus of the dentate gyrus and the stratum radiatum of the CA1 region (Weiland et al. 1997; Shughrue et al. 1997; Laflamme et al. 1998). Nevertheless, the presence of an estrogen responsive element in the promoter of the rat NMDA receptor subunit 1 (Bai and Kusiak 1993) and 2B (Suchanek et al. 1995) genes, which are already cloned, has not been reported; the promoter of the NMDA receptor subunits $2 \mathrm{~A}$ has not been cloned yet. However non-hormone response element containing genes, such as the AP1 response element (Paech et al. 1997), can also respond to the estrogen receptor ligand (Katzenellenbogen et al. 1996). An SP1 motif, which is similar to the AP1 motif, has been found in the NMDA receptor subunit 1 (Bai and Kusiak 1993; Bai and Kusiak 1995) and 2B (Suchanek et al. 1995) promoters. Nevertheless, further investigations with gel shift and DNA footprinting assays are required to clearly answer this potential mechanism of action. Alternatively, the effect of estradiol in the CA1 region of the hippocampus may be through other brain regions, such as the septum and may involve other neurotransmitters, such as acetylcholine (Daniel and Dohanich 2000). Indeed, Daniel and Dohanich (2000) have recently shown that acetylcholine mediates the estrogen-induced increase in the hippocampal NMDA receptor binding and the associated enhancement in working-memory performance.

The NMDA receptor changes observed at the protein level after ovariectomy and hormonal treatments were not associated with similar changes of mRNA levels for this receptor subunits in dentate gyrus of the hippocampus, cerebral cortex, and striatum. This lack of effect may be explained by the cell biology of the transcript versus the final protein localization of NMDA receptors. Transcripts encoding NMDA receptor subunits are localized in the cell bodies of neurons that express these receptors. Hence, the modulation of NMDA receptor binding that we found in a particular brain region may be through modulation of its corresponding transcript in other brain regions containing estrogen receptors. This could also explain why we found changes of both transcript and receptor binding in the CA1 subregion of the hippocampus, which may reflect the short distance between expression of NMDA receptor subunits mRNA in pyramidal cell layers (cell bodies) and expression of their cognate proteins in the oriens and stratum radiatum layers (dendritic projections) (Bernard and Wheal 1994).

The present experiment provides original evidence that tamoxifen and raloxifene, which have shown low estrogenic activity in the uterus, as demonstrated in other studies (see Cosman and Lindsay 1999 for review), both mimic the effects of estradiol on brain L- $\left[{ }^{3} \mathrm{H}\right]$ glutamate, NMDA receptors, and $\left[{ }^{3} \mathrm{H}\right]$ Ro $25-6981$ specific binding and, thus, showed a complete estrogenic activity on these glutamate receptors; this is the first observation of this kind. Recently, an assessment was published dealing with raloxifene effects on cognition and mood in postmenopausal women participating in a randomized, double blind osteoporosis treatment trial. After twelve months of treatment, no clinically significant 
effect of raloxifene on cognitive performance was observed (Nickelsen et al 1999). The penetration of raloxifene in blood-brain protected regions is low and may render the detection of any cognitive effects difficult at the dosage currently used in practice (Wu et al. 1999). However, Wu et al. (1999) reported that systemic administrations of raloxifene reversed the ovariectomyinduced reduction in choline acetyltransferase activity in the hippocampus of rats.

A nonsteroidal estrogen antagonist, CI-628, was shown to have an antagonist effect by effectively preventing estrogen induction of spines on CA1 pyramidal neurons (McEwen et al. 1999). In contrast, CI-628 has an estrogen-like agonist activity on brain monoamine oxidase in corticomedial amygdala (reduction of activity) and on choline acetylase in the preoptic area (increase of activity) (Luine and McEwen 1977). Moreover, tamoxifen was also shown to block the effect of estradiol on dendritic spines of hippocampal neurons (Murphy and Segal 1996). The raloxifene analogue LY117018 has an estrogen-like action on neuroendocrine opiatergic pathways when administered alone in ovariectomized rats, whereas it exerts an anti-estrogenic effect in fertile or ovariectomized rats treated with $17 \beta$-estradiol (Genazzani et al 1999).

The mechanism of action of tamoxifen and raloxifene to modulate NMDA receptors like estradiol as well as their brain regions and tissue specificity factors need further investigation. Our results suggest, however, that the mechanism of action of these two nonsteroidal antiestrogens may be the same than estradiol. However, tamoxifen is an inhibitor of protein kinase $C$ (O'Brian et al. 1986) and it has been found recently that the physiological properties of NMDA receptors in neurons, which are $\mathrm{Ca}^{2+}$-permeable glutamate-gated channels, are modulated by protein kinase $\mathrm{C}$ (Zheng et al. 1999). Hence, tamoxifen may modulate $\left[{ }^{3} \mathrm{H}\right] \mathrm{L}-$ glutamate specific binding and NMDA receptors also via its protein kinase $C$ activity.

We have previously reported that estradiol increases 5-hydroxytryptamine-2A receptor density and expression in rat brain and that raloxifene mimics the effect of estradiol (Cyr et al. 2000b). Moreover, we reported that tamoxifen, in contrast to estradiol and raloxifene, has no significant modulatory effect on brain serotonin 5-hydroxytryptamine-2A receptors of ovariectomized rats, in most brain regions investigated (Cyr et al. 2000b).

Excitotoxicity has been proposed to be implicated in neurodegenerative diseases, such as Parkinson disease (Dunnett and Bjorklund 1999) and Ifenprodil, a blocker of NMDA receptors, has been shown to have antiparkinsonian activity in humans (Montastruc et al. 1997). $17 \beta$-estradiol was reported to protect against NMDAinduced excitotoxicity by direct inhibition of NMDA receptors (Weaver et al. 1997) and recently, a positive association was reported between estrogen use and a lower symptom severity in women with early Parkinson disease no yet taking L-Dopa (Saunders-Pullman et al. 1999).

Since estradiol, tamoxifen, and raloxifene were shown here to decrease striatal NMDA receptors, these hormones mimic the beneficial effect on Parkinson disease seen with excitatory amino acid antagonists. In addition, considering the well established role of the hippocampus (Zola-Morgan et al. 1986; Alvarez et al. 1995) and NMDA receptors (Morris et al. 1982; Bliss and Collingridge 1993) in learning and memory functions, estradiol, tamoxifen, and raloxifene may enhance memory by maintaining NMDA receptors in specific hippocampal regions. Moreover, in the pathophysiology of schizophrenia, human neurochemical and clinical pharmacological data implicate brain glutamatergic abnormalities in the cortex as well as in the hippocampus (Tamminga 1999). Hence, estradiol, tamoxifen, and raloxifene, by their modulation of NMDA receptors and in particular, the subunits 1 and $2 \mathrm{~B}$ of the heteromeric receptor, primarily in the hippocampal CA1 region and the cingulate cortex, may have beneficial effect in neurological disorders such as Alzheimer's disease and schizophrenia.

\section{ACKNOWLEDGMENTS}

The authors are greatly indebted to Dr. Fernand Labrie for the generous gift of raloxifene which was synthesized in the medicinal chemistry division of his laboratory and to F. Hoffman-La Roche Ltd. for the gift of $\left[{ }^{3} \mathrm{H}\right]$ Ro $25-6981$ and Ro 045595. This research was supported by a grant from the Canadian Institutes of Health Research (CIHR) of Canada to T.D.P. M.C. and M.L. are holders of CIHR of Canada studentships.

\section{REFERENCES}

Alvarez P, Zola-Morgan S, Squire LR (1995): Damage limited to the hippocampal region produces long-lasting memory impairment in monkeys. J Neurosci 15:3796-3807

Bai G, Kusiak JW (1993): Cloning and analysis of the 5' flanking sequence of the rat $\mathrm{N}$-methyl-D-aspartate receptor 1 (NMDAR1) gene. Biochim Biophys Acta 1152:197-200

Bai G, Kusiak JW (1995): Functional analysis of the proximal 5'-flanking region of the N-methyl-D-aspartate receptor subunit gene, NMDAR1. J Biol Chem 270:7737-7744

Bernard C, Wheal HV (1994): Model of local connectivity patterns in CA3 and CA1 areas of the hippocampus. Hippocampus 4:497-529

Bliss TV, Collingridge GL (1993): A synaptic model of memory: Long-term potentiation in the hippocampus. Nature 361:31-39

Brann DW, Zamorano PL, Chorich LP, Mahesh VB (1993): Steroid hormone effects on NMDA receptor binding and NMDA receptor mRNA levels in the hypothalamus 
and cerebral cortex of the adult rat. Neuroendocrinology 58:666-672

Christie JM, Jane DE, Monaghan DT (2000): Native N-methylD-aspartate receptors containing NR2A and NR2B subunits have pharmacologically distinct competitive antagonist binding sites. J Pharmacol Exp Ther 292: 1169-1174

Cosman F, Lindsay R (1999): Selective estrogen receptor modulators: Clinical spectrum. Endocr Rev 20:418-434

Cyr M, Ghribi O, Di Paolo T (2000a): Regional and selective effects of oestradiol and progesterone on NMDA and AMPA receptors in the rat brain. J Neuroendocrinol 12:445-452

Cyr M, Landry M, Di Paolo T (2000b): Modulation by estrogen-receptor directed drugs of 5-hydroxytryptamine$2 \mathrm{~A}$ receptors in rat brain. Neuropsychopharmacology 23:69-78

Daniel JM, Dohanich GP (2000): Acethylcholine mediates the estrogen-induced increase in hippocampal NMDA receptor binding and the associated enhancement in working memory performance. Soc Neurosci 26:1675, Abstr 627.6

Di Paolo T (1994): Modulation of brain dopamine transmission by sex steroids. Rev Neurosci 5:27-41

Dunnett SB, Bjorklund A (1999): Prospects for new restorative and neuroprotective treatments in Parkinson's disease. Nature 399:A32-A39

Fink G, Sumner BE, McQueen JK, Wilson H, Rosie R (1998): Sex steroid control of mood, mental state and memory. Clin Exp Pharmacol Physiol 25:764-775

Fischer G, Mutel V, Trube G, Malherbe P, Kew JN, Mohacsi E, Heitz MP, Kemp JA (1997): Ro 25-6981, a highly potent and selective blocker of N-methyl-D-aspartate receptors containing the NR2B subunit. Characterization in vitro. J Pharmacol Exp Ther 283:1285-1292

Gazzaley AH, Weiland NG, McEwen BS, Morrison JH (1996): Differential regulation of NMDAR1 mRNA and protein by estradiol in the rat hippocampus. J Neurosci 16:6830-6838

Genazzani AR, Bernardi F, Stomati M, Rubino S, Giardina L, Luisi S, Monteleone P, Genazzani AD, Luisi M, Petraglia F (1999): Raloxifene analog LY 117018 effects on central and peripheral beta-endorphin. Gynecol Endocrinol 13:249-258

Gu G, Varoqueaux F, Simerly RB (1999): Hormonal regulation of glutamate receptor gene expression in the anteroventral periventricular nucleus of the hypothalamus. J Neurosci 19:3213-3222

Henderson VW (1997): Estrogen, cognition, and a woman's risk of Alzheimer's disease. Am J Med 103:11S-18S

Hollmann M, Boulter J, Maron C, Beasley L, Sullivan J, Pecht G, Heinemann S (1993): Zinc potentiates agonistinduced currents at certain splice variants of the NMDA receptor. Neuron 10:943-954

Inestrosa NC, Marzolo MP, Bonnefont AB (1998): Cellular and molecular basis of estrogen's neuroprotection. Potential relevance for Alzheimer's disease. Mol Neurobiol 17:73-86

Jaarsma D, Sebens JB, Korf J (1993): Glutamate dehydrogenase improves binding of [3H]CGP39653 to NMDA receptors in the autoradiographic assay. J Neurosci Methods 46:133-138

Katzenellenbogen JA, O'Malley BW, Katzenellenbogen BS (1996): Tripartite steroid hormone receptor pharmacology: Interaction with multiple effector sites as a basis for the cell- and promoter-specific action of these hormones. Mol Endocrinol 10:119-131

Laflamme N, Nappi RE, Drolet G, Labrie C, Rivest S (1998): Expression and neuropeptidergic characterization of estrogen receptors (ERalpha and ERbeta) throughout the rat brain: Anatomical evidence of distinct roles of each subtype. J Neurobiol 36:357-378

Laurie DJ, Seeburg PH (1994): Ligand affinities at recombinant N-methyl-D-aspartate receptors depend on subunit composition. Eur J Pharmacol 268:335-345

Levenson AS, Jordan VC (1999): Selective oestrogen receptor modulation: molecular pharmacology for the millennium. Eur J Cancer 35:1974-1985

Loy R, Gerlach JL, McEwen BS (1988): Autoradiographic localization of estradiol-binding neurons in the rat hippocampal formation and entorhinal cortex. Brain Res 467:245-251

Lu D, Healy DJ, Young EA, Huang GC, Isgor C, Akil H, Meador-Woodruff JH (2000): Hippocampal NMDA receptor expression during the estrous cycle. Soc Neurosci 26:1647, Abstr 617.11

Luine VN, McEwen BS (1977): Effects of an estrogen antagonist on enzyme activities and $[3 \mathrm{H}]$ estradiol nuclear binding in uterus, pituitary and brain. Endocrinology 100:903-910

Lynch DR, Anegawa NJ, Verdoorn T, Pritchett DB (1994): N-methyl-D-aspartate receptors: Different subunit requirements for binding of glutamate antagonists, glycine antagonists, and channel-blocking agents. Mol Pharmacol 45:540-545

Maggi A, Susanna L, Bettini E, Mantero G, Zucchi I (1989): Hippocampus: A target for estrogen action in mammalian brain. Mol Endocrinol 3:1165-1170

Martel C, Labrie C, Belanger A, Gauthier S, Merand Y, Li X, Provencher L, Candas B, Labrie F (1998): Comparison of the effects of the new orally active antiestrogen EM-800 with ICI 182780 and toremifene on estrogen-sensitive parameters in the ovariectomized mouse. Endocrinology 139:2486-2492

Marti T, Benke D, Mertens S, Heckendorn R, Pozza M, Allgeier H, Angst C, Laurie D, Seeburg P, Mohler H (1993): Molecular distinction of three N-methyl-D-aspartate-receptor subtypes in situ and developmental receptor maturation demonstrated with the photoaffinity ligand 125I-labeled CGP 55802A. Proc Natl Acad Sci U S A 90:8434-8438

McEwen BS, Tanapat P, Weiland NG (1999): Inhibition of dendritic spine induction on hippocampal CA1 pyramidal neurons by a nonsteroidal estrogen antagonist in female rats. Endocrinology 140:1044-1047

Montastruc JL, Rascol O, Senard JM (1997): Glutamate antagonists and Parkinson's disease: A review of clinical data. Neurosci Biobehav Rev 21:477-480

Monyer H, Sprengel R, Schoepfer R, Herb A, Higuchi M, Lomeli H, Burnashev N, Sakmann B, Seeburg PH (1992): 
Heteromeric NMDA receptors: Molecular and functional distinction of subtypes. Science 256:1217-1221

Moriyoshi K, Masu M, Ishii T, Shigemoto R, Mizuno N, Nakanishi S (1991): Molecular cloning and characterization of the rat NMDA receptor. Nature 354:31-37

Morris RG, Garrud P, Rawlins JN, O'Keefe J (1982): Place navigation impaired in rats with hippocampal lesions. Nature 297:681-683

Mugnaini M, van Amsterdam FT, Ratti E, Trist DG, Bowery NG (1996): Regionally different N-methyl-D-aspartate receptors distinguished by ligand binding and quantitative autoradiography of [3H]-CGP 39653 in rat brain. Br J Pharmacol 119:819-828

Murphy DD, Segal M (1996): Regulation of dendritic spine density in cultured rat hippocampal neurons by steroid hormones. J Neurosci 16:4059-4068

Mutel V, Buchy D, Klingelschmidt A, Messer J, Bleuel Z, Kemp JA, Richards JG (1998): In vitro binding properties in rat brain of [3H]Ro 25-6981, a potent and selective antagonist of NMDA receptors containing NR2B subunits. J Neurochem 70:2147-2155

Nickelsen T, Lufkin EG, Riggs BL, Cox DA, Crook TH (1999): Raloxifene hydrochloride, a selective estrogen receptor modulator: safety assessment of effects on cognitive function and mood in postmenopausal women. Psychoneuroendocrinology 24:115-128

O'Brian CA, Liskamp RM, Solomon DH, Weinstein IB (1986): Triphenylethylenes: A new class of protein kinase C inhibitors. J Natl Cancer Inst 76:1243-1246

Paech K, Webb P, Kuiper GG, Nilsson S, Gustafsson J, Kushner PJ, Scanlan TS (1997): Differential ligand activation of estrogen receptors ERalpha and ERbeta at AP1 sites. Science 277:1508-1510

Paxinos G, Watson C (1982): The Rat Brain in Stereotaxic Coordinates. New York, Academic Press

Pfaff D, Keiner M (1973): Atlas of estradiol-concentrating cells in the central nervous system of the female rat. J Comp Neurol 151:121-158

Sato M, Rippy MK, Bryant HU (1996): Raloxifene, tamoxifen, nafoxidine, or estrogen effects on reproductive and nonreproductive tissues in ovariectomized rats. Faseb J 10:905-912

Saunders-Pullman R, Gordon-Elliott J, Parides M, Fahn S, Saunders HR, Bressman S (1999): The effect of estrogen replacement on early Parkinson's disease. Neurology 52:1417-1421

Shughrue PJ, Lane MV, Merchenthaler I (1997): Comparative distribution of estrogen receptor-alpha and -beta mRNA in the rat central nervous system. J Comp Neurol 388:507-525

Sills MA, Fagg G, Pozza M, Angst C, Brundish DE, Hurt SD, Wilusz EJ, Williams M (1991): [3H]CGP 39653: A new $\mathrm{N}$-methyl-D-aspartate antagonist radioligand with low nanomolar affinity in rat brain. Eur J Pharmacol 192:19-24

Simpkins JW, Singh M, Bishop J (1994): The potential role for estrogen replacement therapy in the treatment of the cognitive decline and neurodegeneration associated with Alzheimer's disease. Neurobiol Aging 15:S195-S197

Suchanek B, Seeburg PH, Sprengel R (1995): Gene structure of the murine $\mathrm{N}$-methyl D-aspartate receptor subunit NR2C. J Biol Chem 270:41-44

Sugihara H, Moriyoshi K, Ishii T, Masu M, Nakanishi S (1992): Structures and properties of seven isoforms of the NMDA receptor generated by alternative splicing. Biochem Biophys Res Commun 185:826-832

Tamminga C (1999): Glutamatergic aspects of schizophrenia. Br J Psychiatry Suppl 37:12-15

Tang MX, Jacobs D, Stern Y, Marder K, Schofield P, Gurland B, Andrews H, Mayeux R (1996): Effect of oestrogen during menopause on risk and age at onset of Alzheimer's disease. Lancet 348:429-432

Toran-Allerand CD, Hashimoto K, Greenough WT, Saltarelli M (1983): Sex steroids and the development of the newborn mouse hypothalamus and preoptic area in vitro. III. Effects of estrogen on dendritic differentiation. Brain Res 283:97-101

Weaver CE Jr, Park-Chung M, Gibbs TT, Farb DH (1997): 17beta-Estradiol protects against NMDA-induced excitotoxicity by direct inhibition of NMDA receptors. Brain Res 761:338-341

Weiland NG (1992): Estradiol selectively regulates agonist binding sites on the $\mathrm{N}$-methyl-D-aspartate receptor complex in the CA1 region of the hippocampus. Endocrinology 131:662-668

Weiland NG, Orikasa C, Hayashi S, McEwen BS (1997): Distribution and hormone regulation of estrogen receptor immunoreactive cells in the hippocampus of male and female rats. J Comp Neurol 388:603-612

Woolley CS, McEwen BS (1992): Estradiol mediates fluctuation in hippocampal synapse density during the estrous cycle in the adult rat. J Neurosci 12:2549-2554

Woolley CS, Weiland NG, McEwen BS, Schwartzkroin PA (1997): Estradiol increases the sensitivity of hippocampal CA1 pyramidal cells to NMDA receptor-mediated synaptic input: Correlation with dendritic spine density. J Neurosci 17:1848-1859

Wu X, Glinn MA, Ostrowski NL, Su Y, Ni B, Cole HW, Bryant HU, Paul SM (1999): Raloxifene and estradiol benzoate both fully restore hippocampal choline acetyltransferase activity in ovariectomized rats. Brain Res 847:98-104

Zheng X, Zhang L, Wang AP, Bennett MV, Zukin RS (1999): Protein kinase $C$ potentiation of N-methyl-D-aspartate receptor activity is not mediated by phosphorylation of N-methyl-D-aspartate receptor subunits. Proc Natl Acad Sci U S A 96:15262-15267

Zola-Morgan S, Squire LR, Amaral DG (1986): Human amnesia and the medial temporal region: Enduring memory impairment following a bilateral lesion limited to field CA1 of the hippocampus. J Neurosci 6:2950-2967 